\title{
The Cariboo Alpine Mesonet: sub-hourly hydrometeorological observations of British Columbia's Cariboo Mountains and surrounding area since 2006
}

\author{
Marco A. Hernández-Henríquez ${ }^{1}$, Aseem R. Sharma ${ }^{2}$, Mark Taylor ${ }^{1}$, Hadleigh D. Thompson $^{2}$, and \\ Stephen J. Déry ${ }^{1}$ \\ ${ }^{1}$ Environmental Science and Engineering Program, University of Northern British Columbia, \\ 3333 University Way, Prince George, British Columbia, V2N 4Z9, Canada \\ ${ }^{2}$ Natural Resources and Environmental Studies Program, University of Northern British Columbia, \\ 3333 University Way, Prince George, British Columbia, V2N 4Z9, Canada
}

Correspondence: Stephen J. Déry (sdery@unbc.ca)

Received: 27 March 2018 - Discussion started: 12 April 2018

Revised: 14 August 2018 - Accepted: 23 August 2018 - Published: 11 September 2018

\begin{abstract}
This article presents the development of a sub-hourly database of hydrometeorological conditions collected in British Columbia's (BC's) Cariboo Mountains and surrounding area extending from 2006 to present. The Cariboo Alpine Mesonet (CAMnet) forms a network of 11 active hydrometeorological stations positioned at strategic locations across mid- to high elevations of the Cariboo Mountains. This mountain region spans $44150 \mathrm{~km}^{2}$, forming the northern extension of the Columbia Mountains. Deep fjord lakes along with old-growth western redcedar and hemlock forests reside in the lower valleys, montane forests of Engelmann spruce, lodgepole pine and subalpine fir permeate the mid-elevations, while alpine tundra, glaciers and several large ice fields cover the higher elevations. The automatic weather stations typically measure air and soil temperature, relative humidity, atmospheric pressure, wind speed and direction, rainfall and snow depth at 15 min intervals. Additional measurements at some stations include shortwave and longwave radiation, near-surface air, skin, snow, or water temperature, and soil moisture, among others. Details on deployment sites, the instrumentation used and its precision, the collection and quality control process are provided. Instructions on how to access the database at Zenodo, an online public data repository, are also furnished (https://doi.org/10.5281/zenodo.1195043). Information on some of the challenges and opportunities encountered in maintaining continuous and homogeneous time series of hydrometeorological variables and remote field sites is provided. The paper also summarizes ongoing plans to expand CAMnet to better monitor atmospheric conditions in BC's mountainous terrain, efforts to push data online in (near-)real time, availability of ancillary data and lessons learned thus far in developing this mesoscale network of hydrometeorological stations in the data-sparse Cariboo Mountains.
\end{abstract}

\section{Introduction}

As in many regions worldwide, amplified climate change is altering the hydrometeorology of mountainous basins in northern British Columbia (BC). Climate change in northcentral BC's mountains is accelerating permafrost degradation and thawing (Hasler et al., 2015), snowpack thinning (Kang et al., 2016) and glacier retreat (Beedle et al., 2015) and decreasing the proportion of snowfall to total precip- itation (Kang et al., 2016). The Cariboo Alpine Mesonet (CAMnet; MacLeod and Déry, 2007) is a mesoscale network $\left(\sim 100 \mathrm{sm}^{2}\right)$ initiated in 2006 by the Northern Hydrometeorology Group (NHG) at the University of Northern British Columbia (UNBC) to collect long-term hydroclimatological data for the Cariboo Mountains and surrounding regions. Given the remote and difficult terrain in mountain environments where atmospheric and snowpack conditions vary substantially over small spatial scales, paucity of 


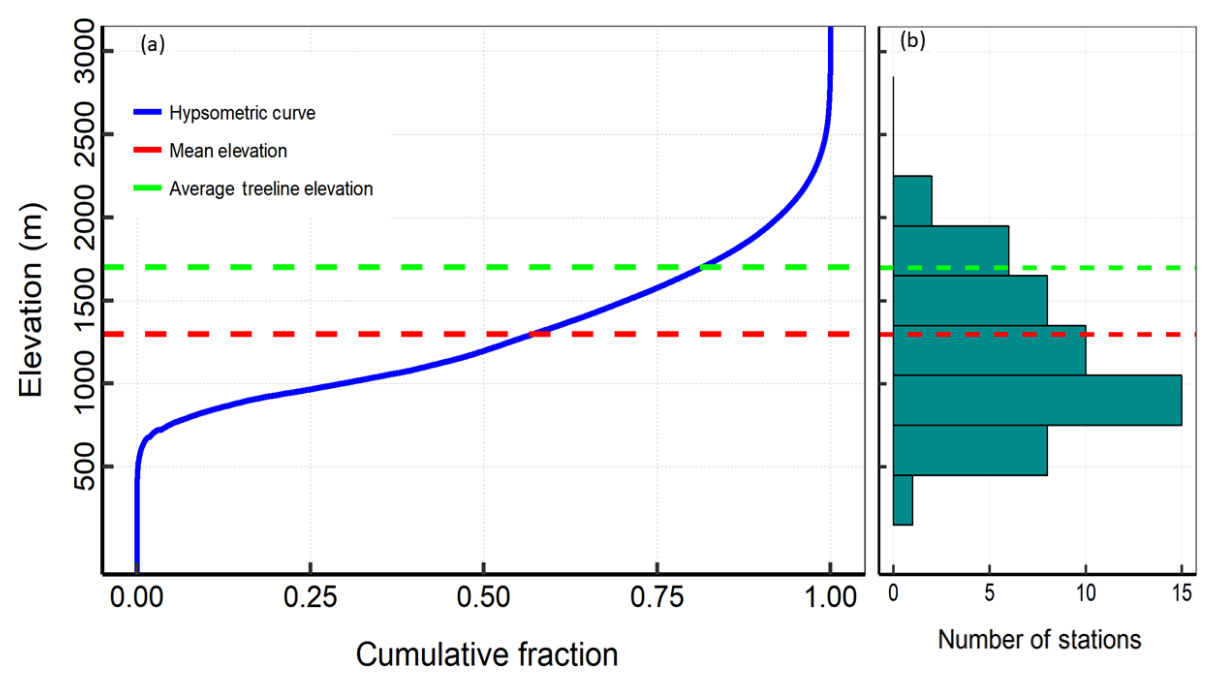

Figure 1. (a) Hypsometric curve showing the cumulative fraction of the elevation ranges in the Cariboo Mountains region. (b) The number of active weather stations at different elevations within the Cariboo Mountains region.

observational climate data exists in the world's alpine regions (Beniston, 2006; Bradley et al., 2004). This was indeed the case for the Cariboo Mountains where there is relatively good coverage of meteorological stations below the treeline elevation of $1700 \mathrm{~m}$ a.s.l.; however, coverage is particularly sparse in the higher elevations (Fig. 1). Indeed, there are only 49 active weather stations in the Cariboo Mountains region that spans $44150 \mathrm{~km}^{2}$, equivalent to a density of 1.1 station per $1000 \mathrm{~km}^{2}$, which is well below the range of one station per $100-250 \mathrm{~km}^{2}$ recommended by the World Meteorological Organization (WMO) (Miles et al., 2003) and found in other regions of Canada (e.g., Mekis et al., 2018) or in mountainous environments such as the European Alps (Gubler et al., 2017). This issue is especially acute at higher elevations as there are currently only six active meteorological stations above the treeline in the Cariboo Mountains, three of which are part of CAMnet. Thus, CAMnet fills an important observational gap to detect climate change at high elevations and its impacts to snowpacks, glaciers and water resources.

Since the summer of 2006, we have established 11 active and 7 deactivated automatic weather stations and 2 radio repeater stations in valley and mountain settings, at elevations ranging from 683 to $2105 \mathrm{~m}$ a.s.l. (Déry et al., 2010). Data from these weather stations have supported modelling studies of seasonal snowpack evolution (Younas et al., 2017), blowing snow fluxes (Déry et al., 2010), turbulent fluxes on a mountain glacier (Radić et al., 2017), glacial retreat (Beedle et al., 2009, 2015) and pro-glacial sediment transport dynamics (Leggat et al., 2015; Stott et al., 2016). These data have also been used to validate remote sensing products of snow (Tong et al., 2009a, b, 2010), gridded meteorological datasets (Sharma and Déry, 2016) and output from numerical weather prediction models over complex terrain (Schirmer and Jamieson, 2015). More recently, CAMnet stations have provided meteorological data to researchers investigating the long-term physical, chemical and biological effects of the Mount Polley mine tailings impoundment breach in August 2014 (see Sect. 3.2) (Petticrew et al., 2015). The CAMnet meteorological datasets thus have the potential to serve multiple users including the operational forecasting and climate modelling communities, the developers of gridded climate datasets such as ANUSPLIN (McKenney et al., 2011) and ClimateWNA (Wang et al., 2012), water resource managers, natural hazard mitigators (e.g., for the control of wildfire activity and avalanche potential), and the tourism and recreation industries (e.g., heli-skiing operations).

The purpose of this article is to document the development and current status of CAMnet, including the setting in which the meteorological stations are deployed; the hydrometeorological variables being monitored and collected; efforts to quality control the data; and data processing, archiving and availability. The paper also describes some of the challenges and opportunities incurred during the data collection process in the remote terrain of the Cariboo Mountains, the availability of ancillary data and prospects for future expansion of the network in the Cariboo Mountains and beyond.

\section{Study area}

The Cariboo Mountains region spans $\sim 44150 \mathrm{~km}^{2}$ in the central interior of $\mathrm{BC}$, forming the northernmost range of the Columbia Mountains between the Interior Plateau and Rocky Mountain Trench (Fig. 2). Elevations in the Cariboo Mountains range from $330 \mathrm{~m}$ a.s.l. in the valley bottoms to $3520 \mathrm{~m}$ a.s.l. at its highest peak, Mount Sir Wilfrid Laurier (Sharma, 2014). The climate in the Cariboo Mountains remains drier than the Coast Mountains to the west, but wetter than the Interior Plateau to the west and Rocky Mountains 


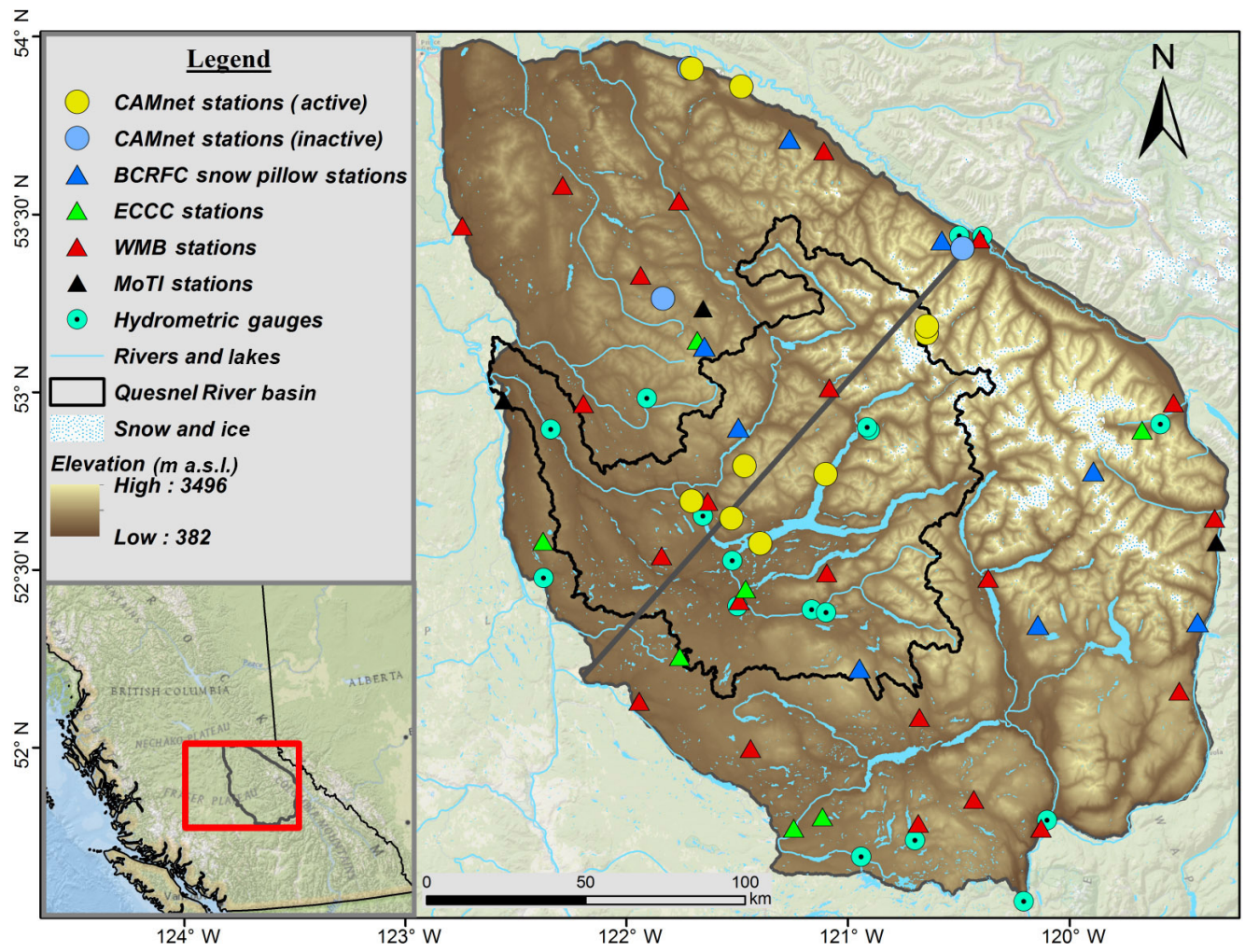

Figure 2. Topographic map of the Cariboo Mountains region including the Quesnel River basin. Dots and triangles show the location of active weather, snow pillow and hydrometric stations operated by different agencies in this region including the BC River Forecast Centre (BCRFC), Environment and Climate Change Canada (ECCC), BC Wildfire Management Branch (WMB), and BC Ministry of Transportation and Infrastructure (MoTI). The grey line depicts a transect between Williams Lake and McBride, BC, for which climate data are extracted (see Fig. 6).

to the east (Beedle et al., 2015). On the windward side of the Cariboo Mountains in Quesnel, BC, the total annual precipitation averages $\approx 500 \mathrm{~mm}$ but increases to $>2000 \mathrm{~mm}$ $150 \mathrm{~km}$ further east (Burford et al., 2009). Annual air temperature averages $1.8^{\circ} \mathrm{C} \pm 1.0^{\circ} \mathrm{C}$ over the Cariboo Mountains region, with January being the coldest month (average air temperature of $-10.1^{\circ} \mathrm{C} \pm 1.1^{\circ} \mathrm{C}$ ) and July the warmest (average air temperature of $12.9^{\circ} \mathrm{C} \pm 1.8^{\circ} \mathrm{C}$ ). Average annual total precipitation in this region reaches $739 \mathrm{~mm} \pm 140 \mathrm{~mm}$ with nearly half falling as snow (Sharma, 2014). The relative amount of snow accumulation increases with altitude (Burford et al., 2009). Peak snow accumulation commonly surpasses $1000 \mathrm{~mm}$ water equivalent near the treeline (Déry et al., 2014) and snow cover often persists from October through June (Tong et al., 2009a). Annual peak flows in the creeks and rivers draining the Cariboo Mountains follow snowmelt with general declines in summer although moderated through glacier melt into fall prior to entering the lowflow season during winter when precipitation accumulates in the seasonal snowpack (Burford et al., 2009).

Within the North Cariboo region of BC lies the $12000 \mathrm{~km}^{2}$ Quesnel River basin, covering six biogeoclimatic zones (Boreal Altai Fescue Alpine, Interior Mountain- heather Alpine, Engelmann Spruce-Subalpine Fir, Interior Cedar-Hemlock, Sub-boreal Spruce, and Sub-boreal Pine and Spruce). The terrain varies from relatively flat to mountainous with a mean elevation of $1375 \mathrm{~m}$ a.s.l, rising from $\sim 500 \mathrm{~m}$ a.s.l. in the west to $\sim 3000 \mathrm{~m}$ a.s.l. in the northeast. Glaciers cover $\sim 2 \%$ of the watershed while deep fjord lakes (e.g., Quesnel Lake with depths surpassing $500 \mathrm{~m}$ ) reside in steep valleys. The mountainous terrain and snowy climate provide a suitable environment for the world's largest inland temperate rainforest (Stevenson et al., 2011; Farley, 1979). Situated along the Quesnel River sits UNBC's Quesnel River Research Centre (QRRC; http://www.unbc.ca/qrrc, last access: 3 July 2018) that includes a large workshop, laboratory, office space and housing residence. This unique combination of landscape and research infrastructure makes the watershed an ideal location for collecting high-elevation hydrometeorological data. 
Table 1. Details for each CAMnet station.

\begin{tabular}{|c|c|c|c|c|c|c|c|}
\hline Station & Name & $\begin{array}{l}\text { Latitude } \\
\left({ }^{\circ} \mathrm{N}\right)\end{array}$ & $\begin{array}{l}\text { Longitude } \\
\left({ }^{\circ} \mathrm{W}\right)\end{array}$ & $\begin{array}{r}\text { Elevation } \\
\text { (m a.s.l.) }\end{array}$ & Terrain & $\begin{array}{l}\text { Date of } \\
\text { deployment }\end{array}$ & $\begin{array}{l}\text { Date of } \\
\text { decommission }\end{array}$ \\
\hline 1 & QRRC $^{\mathrm{a}}$ & $52^{\circ} 37^{\prime} 06^{\prime \prime}$ & $121^{\circ} 35^{\prime} 24^{\prime \prime}$ & 743 & Flat short grass & 11 Aug 2006 & \\
\hline 2 & Spanish Mountain & $52^{\circ} 33^{\prime} 48^{\prime \prime}$ & $121^{\circ} 24^{\prime} 35^{\prime \prime}$ & 1509 & Sloped forest regrowth & 30 Jun 2006 & \\
\hline 3 & Browntop Mountain & $52^{\circ} 42^{\prime} 28^{\prime \prime}$ & $121^{\circ} 20^{\prime} 02^{\prime \prime}$ & 2030 & Alpine ridge & 23 Aug 2006 & \\
\hline 4 & Blackbear Mountain radio repeater ${ }^{b}$ & $52^{\circ} 36^{\prime} 53^{\prime \prime}$ & $121^{\circ} 26^{\prime} 12^{\prime \prime}$ & 1590 & Sloped forest regrowth & 24 Aug 2006 & \\
\hline 5 & Upper Castle Creek Glacier & $53^{\circ} 02^{\prime} 34^{\prime \prime}$ & $120^{\circ} 26^{\prime} 15^{\prime \prime}$ & 2105 & Bedrock ridge & 28 Aug 2007 & \\
\hline 6 & Mount Tom & $53^{\circ} 11^{\prime} 32^{\prime \prime}$ & $121^{\circ} 39^{\prime} 49^{\prime \prime}$ & 1490 & Sloped cutblock & 20 Sep 2007 & 15 Sep 2009 \\
\hline 7 & Lower Castle Creek Glacier & $53^{\circ} 03^{\prime} 45^{\prime \prime}$ & $120^{\circ} 26^{\prime} 04^{\prime \prime}$ & 1803 & Flat moraine & 13 Aug 2008 & \\
\hline 8 & Castle Creek Glacier radio repeater & $53^{\circ} 02^{\prime} 03^{\prime \prime}$ & $120^{\circ} 25^{\prime} 57^{\prime \prime}$ & 2219 & Bedrock ridge & 1 Aug 2009 & \\
\hline 9 & Ancient Forest & $53^{\circ} 46^{\prime} 21^{\prime \prime}$ & $121^{\circ} 13^{\prime} 44^{\prime \prime}$ & 774 & Old-growth forest & 7 Oct 2009 & \\
\hline 10 & Lunate Creek & $53^{\circ} 49^{\prime} 56^{\prime \prime}$ & $121^{\circ} 27^{\prime} 32^{\prime \prime}$ & 953 & Regenerating clear cut & 17 May 2010 & \\
\hline 11 & Lucille Mountain & $53^{\circ} 16^{\prime} 22^{\prime \prime}$ & $120^{\circ} 14^{\prime} 18^{\prime \prime}$ & 1587 & Planted cutblock & 7 Jul 2010 & $10 \mathrm{Jul} 2013$ \\
\hline 12 & Upper Lunate Creek & $53^{\circ} 50^{\prime} 02^{\prime \prime}$ & $121^{\circ} 28^{\prime} 21^{\prime \prime}$ & 1134 & Regenerating clear cut & 23 Aug 2011 & 29 Jul 2012 \\
\hline 13 & Ness Lake & $54^{\circ} 01^{\prime} 27^{\prime \prime}$ & $123^{\circ} 05^{\prime} 35^{\prime \prime}$ & 763 & Flat short grass & 30 Jul 2012 & \\
\hline 14 & Coles Lake & $59^{\circ} 47^{\prime} 22^{\prime \prime}$ & $122^{\circ} 36^{\prime} 43^{\prime \prime}$ & 479 & Flat - bulldozed & 11 Jun 2013 & 29 Jul 2015 \\
\hline 15 & Kiskatinaw & $55^{\circ} 45^{\prime} 04^{\prime \prime}$ & $120^{\circ} 31^{\prime} 27^{\prime \prime}$ & 726 & Flat long grass & 20 Aug 2015 & 15 Jun 2017 \\
\hline 16 & Tatuk Lake & $53^{\circ} 32^{\prime} 41^{\prime \prime}$ & $124^{\circ} 16^{\prime} 36^{\prime \prime}$ & 938 & Flat short grass & 29 Sep 2015 & \\
\hline 17 & Plato Point & $52^{\circ} 29^{\prime} 15^{\prime \prime}$ & $121^{\circ} 17^{\prime} 03^{\prime \prime}$ & 728 & Sandy beach & 17 Aug 2016 & \\
\hline 18 & Long Creek & $52^{\circ} 40^{\prime} 06^{\prime \prime}$ & $120^{\circ} 57^{\prime} 34^{\prime \prime}$ & 728 & Gravel beach & 26 Jun 2017 & \\
\hline
\end{tabular}

${ }^{a}$ Quesnel River Research Centre. ${ }^{\mathrm{b}}$ The Blackbear Mountain weather station was dismantled in July 2007 and became a radio repeater station to facilitate communication and data download at the QRRC.

\section{Hydrometeorological stations}

\subsection{Overview}

As of 31 March 2018, CAMnet comprises 11 active meteorological stations and two radio repeaters positioned at strategic locations, predominantly at mid- to high elevations within the Quesnel River basin and the surrounding Cariboo Mountains of north-central BC (Figs. 3 and 4, Table 1). Specifically, the Quesnel watershed hosts five active CAMnet stations, the Upper and Lower Castle Creek Glacier stations reside on its eastern divide, and four others reside near Prince George and its vicinity. At each station, instruments measure atmospheric pressure, $2 \mathrm{~m}$ air temperature and relative humidity (with respect to water), wind speed and direction, liquid precipitation and snow depth among other variables that are only measured at specific stations (e.g., soil moisture, solar radiation, and near-surface air, snow, soil and water temperature) (Supplement Table S1). All the sensors are powered by $12 \mathrm{~V}$ batteries charged during the day by solar panels; however, both the QRRC and Ness Lake weather stations run on alternating current (AC) supplemented by batteries in case of electrical interruptions. The QRRC station records incoming and outgoing shortwave and longwave radiation in addition to the parameters measured by the remote stations. Table 2 lists the specifications of each instrument, including their accuracy and precision. Data loggers record the meteorological parameters and store data every $15 \mathrm{~min}$. Stations located within the QRRC's proximity periodically send data via spread-spectrum radio to the operational base computer located in the housing residence (see Sect. 4.2). Despite remote data access for several stations, site visits for data downloads and routine maintenance occur at a minimum once a year at all stations (see Sect. 4.1).

\subsection{Chronological development}

Having identified a significant observational gap in the Cariboo Mountains and addressing the needs of the QRRC's expanding research operations, UNBC's NHG established its first four CAMnet weather stations during the summer of 2006 in the vicinity of Likely, BC. Given the QRRC's availability to other UNBC researchers and those at other institutions, a dedicated effort was made to establish a standard meteorological station with an extended suite of instrumentation on the research centre's property. This station became operational on 11 August 2006 and is located $2 \mathrm{~km}$ southwest of Likely, BC, in an incised valley $\sim 100 \mathrm{~m}$ south of the Quesnel River at an elevation of $743 \mathrm{~m}$ a.s.l. This is the only CAMnet weather station with a permanent $10 \mathrm{~m}$ tower with a concrete foundation for the tower footing and guy wires for anchoring. There is $50 \%$ sky visibility at the site and, given its location, accessibility remains easy. Vegetation consists of grasses, western redcedar, hemlock and some Douglas fir. A CR23X data logger controls the entire weather station and accommodates the additional programming capacity and power supply needed to run a full radiometer and associated heater, installed $5 \mathrm{~m}$ above bare ground. Winds are measured at $10 \mathrm{~m}$ above the surface while air temperature and relative humidity are gauged $2 \mathrm{~m}$ above bare ground. This site also benefits from access to AC power to operate a heated precipitation gauge surrounded by an Alter shield. Data are periodically sent to the QRRC operational base computer via spread-spectrum radio. 
Table 2. Specifications for sensors used at each CAMnet station. NA - not available.

\begin{tabular}{|c|c|c|c|c|c|c|}
\hline Sensor & Model & Measurements & Units & Sensitivity & Accuracy & Operating range \\
\hline $\begin{array}{l}\text { Spread-spectrum ra- } \\
\text { dio }\end{array}$ & RF401 & NA & NA & $-109 \mathrm{dBm}$ & NA & -25 to $50^{\circ} \mathrm{C}$ \\
\hline \multirow[t]{3}{*}{$\begin{array}{l}\text { Barometric pressure } \\
\text { sensor }\end{array}$} & $\begin{array}{l}61205 \mathrm{~V} \\
61205 \mathrm{~V}-10\end{array}$ & $\begin{array}{l}\text { Atmospheric } \\
\text { pressure }\end{array}$ & $\mathrm{hPa}$ & $0.1 \mathrm{hPa}$ & $\pm 0.5 \mathrm{hPa}$ & $600-1100 \mathrm{hPa}$ \\
\hline & $61302 \mathrm{~V}$ & $\begin{array}{l}\text { Atmospheric } \\
\text { pressure }\end{array}$ & $\mathrm{hPa}$ & $0.1 \mathrm{hPa}$ & $\begin{array}{l} \pm 0.2 \mathrm{hPa}\left(25^{\circ} \mathrm{C}\right) \\
\pm 0.3 \mathrm{hPa}\left(-50 \text { to }+60^{\circ} \mathrm{C}\right)\end{array}$ & $500-1100 \mathrm{hPa}$ \\
\hline & CS106 & $\begin{array}{l}\text { Atmospheric } \\
\text { pressure }\end{array}$ & $\mathrm{hPa}$ & NA & $\begin{array}{l} \pm 0.3 \mathrm{hPa}\left(20^{\circ} \mathrm{C}\right) \\
\pm 0.6 \mathrm{hPa}\left(0 \text { to } 40{ }^{\circ} \mathrm{C}\right) \\
\pm 1.0 \mathrm{hPa}\left(-20 \text { to }+45^{\circ} \mathrm{C}\right) \\
\pm 1.5 \mathrm{hPa}\left(-40 \text { to }+60{ }^{\circ} \mathrm{C}\right)\end{array}$ & $\begin{array}{l}-40 \text { to } 60^{\circ} \mathrm{C} \\
500-1100 \mathrm{hPa}\end{array}$ \\
\hline \multirow{6}{*}{$\begin{array}{l}\text { Relative humidity } \\
\text { and air temperature } \\
\text { probe }\end{array}$} & $\begin{array}{l}\text { HMP35C } \\
\text { HMP45C } \\
\text { HMP45C } 212\end{array}$ & Air temperature & ${ }^{\circ} \mathrm{C}$ & NA & $\pm 0.1^{\circ} \mathrm{C}$ & \multirow[t]{4}{*}{-40 to $60^{\circ} \mathrm{C}$} \\
\hline & & Relative humidity & $\%$ & NA & $\begin{array}{l} \pm 2 \%(0-90 \% \mathrm{RH}) \text { at } 20{ }^{\circ} \mathrm{C} \\
\pm 3 \%(90-100 \% \mathrm{RH}) \text { at } 20^{\circ} \mathrm{C}\end{array}$ & \\
\hline & HMP60 & Air temperature & ${ }^{\circ} \mathrm{C}$ & NA & $\pm 0.6^{\circ} \mathrm{C}\left(-40\right.$ to $\left.+60^{\circ} \mathrm{C}\right)$ & \\
\hline & & Relative humidity & $\%$ & NA & $\begin{array}{l} \pm 3 \% \text { RH }(0-90 \% \text { RH }) \\
\pm 5 \% \text { RH }(90-100 \% \text { RH })\end{array}$ & \\
\hline & $\mathrm{HC}-\mathrm{S} 3$ & Air temperature & ${ }^{\circ} \mathrm{C}$ & NA & $\pm 0.2^{\circ} \mathrm{C}\left(-30\right.$ to $\left.60^{\circ} \mathrm{C}\right)$ & -40 to $60^{\circ} \mathrm{C}$ \\
\hline & & Relative humidity & $\%$ & NA & $\pm 1.5 \%$ at $23^{\circ} \mathrm{C}$ & \\
\hline \multirow[t]{2}{*}{ Temperature probe } & $107 \mathrm{~B}$ & Soil temperature & ${ }^{\circ} \mathrm{C}$ & NA & $\begin{array}{l} \pm 0.4^{\circ} \mathrm{C}\left(-24 \text { to } 48^{\circ} \mathrm{C}\right) \\
\pm 0.9^{\circ} \mathrm{C}\left(-35 \text { to } 50^{\circ} \mathrm{C}\right)\end{array}$ & \multirow[t]{2}{*}{-50 to $100^{\circ} \mathrm{C}$} \\
\hline & $\begin{array}{l}109 \\
109 \mathrm{~B}\end{array}$ & Soil temperature & ${ }^{\circ} \mathrm{C}$ & NA & $\begin{array}{l} \pm 0.60^{\circ} \mathrm{C}\left(-50 \text { to } 70{ }^{\circ} \mathrm{C}\right) \\
\pm 0.25^{\circ} \mathrm{C}\left(-10 \text { to } 70^{\circ} \mathrm{C}\right)\end{array}$ & \\
\hline \multirow[t]{2}{*}{$\begin{array}{l}\text { RM Young wind } \\
\text { monitor }\end{array}$} & $\begin{array}{l}05103-10 \\
05103-45\end{array}$ & Wind speed & $\mathrm{ms}^{-1}$ & NA & $\pm 0.3 \mathrm{~m} \mathrm{~s}^{-1}$ & \multirow[t]{2}{*}{-50 to $50^{\circ} \mathrm{C}$} \\
\hline & & Wind direction & degrees & NA & $\pm 5^{\circ}$ & \\
\hline \multirow[t]{4}{*}{$\begin{array}{l}\text { Tipping bucket } \\
\text { rain gauge }\end{array}$} & 34-HT-P & $\begin{array}{l}\text { Liquid/solid precipita- } \\
\text { tion }\end{array}$ & $\mathrm{mm}$ & $0.25 \mathrm{~mm}$ per tip & $\begin{array}{l}\text { Precipitation rate: } \\
\pm 0.25 \mathrm{~mm} \text { up to } 20 \mathrm{~mm} \mathrm{~h}^{-1} \\
\pm 3 \% \text { over } 20 \mathrm{~mm} \mathrm{~h}^{-1}\end{array}$ & -20 to $50^{\circ} \mathrm{C}$ \\
\hline & TE525WS & Liquid precipitation & $\mathrm{mm}$ & $\begin{array}{l}0.254 \mathrm{~mm} \\
\text { per tip }\end{array}$ & $\begin{array}{l}\text { Precipitation rate: } \\
\pm 1 \% \text { up to } 25.4 \mathrm{~mm} \mathrm{~h}^{-1} \\
+0,-2.5 \% \text { from } 25.4 \text { to } \\
50.8 \mathrm{~mm} \mathrm{~h}^{-1} \\
+0,-3.5 \% \text { from } 50.8 \text { to } 76.2 \mathrm{~mm} \mathrm{~h}^{-1}\end{array}$ & \multirow[t]{4}{*}{0 to $50^{\circ} \mathrm{C}$} \\
\hline & TE525M & Liquid precipitation & $\mathrm{mm}$ & $0.1 \mathrm{~mm}$ per tip & $\begin{array}{l}\text { Precipitation rate: } \\
\pm 1 \% \text { up to } 25.4 \mathrm{~mm} \mathrm{~h}^{-1} \\
+0,-2.5 \% \text { from } 25.4 \text { to } \\
50.8 \mathrm{~mm} \mathrm{~h}^{-1} \\
+0,-3.5 \% \text { from } 50.8 \text { to } 76.2 \mathrm{~mm} \mathrm{~h}^{-1}\end{array}$ & \\
\hline & TR-525USW & Liquid precipitation & $\mathrm{mm}$ & $0.254 \mathrm{~mm}$ per tip & $\begin{array}{l}\text { Precipitation rate: } \\
1 \% \text { at } 25.4 \mathrm{~mm} \mathrm{~h}^{-1} \text { or less }\end{array}$ & \\
\hline \multirow[t]{2}{*}{$\begin{array}{l}\text { Ultrasonic distance } \\
\text { measurement }\end{array}$} & SR50 & Snow depth & $\mathrm{cm}$ & $0.1 \mathrm{~mm}$ & $\begin{array}{l} \pm 1 \mathrm{~cm} \text { or } 0.4 \% \text { of distance to target } \\
\text { (whichever is greater) }\end{array}$ & \\
\hline & SR50A & Snow depth & $\mathrm{cm}$ & $0.25 \mathrm{~mm}$ & $\begin{array}{l} \pm 1 \mathrm{~cm} \text { or } 0.4 \% \text { of distance to target } \\
\text { (whichever is greater) }\end{array}$ & -45 to $50^{\circ} \mathrm{C}$ \\
\hline \multirow[t]{2}{*}{$\begin{array}{l}\text { Water content } \\
\text { reflectometer }\end{array}$} & CS616 & Soil moisture & $\begin{array}{l}\% \text { volumet- } \\
\text { ric water } \\
\text { content } \\
\text { (VWC) }\end{array}$ & $<0.1 \% \mathrm{VWC}$ & $\begin{array}{l} \pm 2.5 \% \text { VWC using standard calibra- } \\
\text { tion with bulk electrical conductivity } \\
\text { (EC) } \leq 0.5 \mathrm{dS} \mathrm{m}^{-1} \text { and } \\
\text { bulk density } \leq 1.55 \mathrm{~g} \mathrm{~cm}^{-3} \\
\text { in measurement range } \\
0 \text { to } 50 \% \mathrm{VWC}\end{array}$ & 0 to $70^{\circ} \mathrm{C}$ \\
\hline & CS650 & Soil moisture & $\% \mathrm{VWC}$ & $<0.05 \% \mathrm{VWC}$ & $\begin{array}{l} \pm 3 \% \text { (typical with factory VWC } \\
\text { model) where solution } \mathrm{EC}<3 \mathrm{dS} \mathrm{m}^{-1}\end{array}$ & -50 to $70^{\circ} \mathrm{C}$ \\
\hline
\end{tabular}


Table 2. Continued.

\begin{tabular}{|c|c|c|c|c|c|c|}
\hline Sensor & Model & Measurements & Units & Sensitivity & Accuracy & Operating range \\
\hline \multirow{5}{*}{$\begin{array}{l}\text { Radiometer/ } \\
\text { pyranometer }\end{array}$} & CNR1 & $\begin{array}{l}\text { Shortwave up/down, } \\
\text { Longwave up/down }\end{array}$ & $\mathrm{W} \mathrm{m}^{-2}$ & $6.18 \mu \mathrm{V}\left(\mathrm{W} \mathrm{m}^{-2}\right)^{-1}$ & $\pm 10 \%$ of daily totals & -40 to $70^{\circ} \mathrm{C}$ \\
\hline & CMP3 & Shortwave up/down & $\mathrm{W} \mathrm{m}^{-2}$ & 5 to $20 \mu \mathrm{V}\left(\mathrm{W} \mathrm{m}^{-2}\right)^{-1}$ & $\pm 10 \%$ of daily totals & -40 to $80^{\circ} \mathrm{C}$ \\
\hline & SP LITE2 & Shortwave up/down & $\mathrm{W} \mathrm{m}^{-2}$ & $\begin{array}{l}81 \mu \mathrm{V}\left(\mathrm{W} \mathrm{m}^{-2}\right)^{-1} \\
< \pm 2 \% \text { shift per year }\end{array}$ & $\pm 5 \%$ of daily totals & -40 to $80^{\circ} \mathrm{C}$ \\
\hline & LI 200R & Shortwave up/down & $\mathrm{W} \mathrm{m}^{-2}$ & 7 to $15 \mu \mathrm{V}\left(\mathrm{W} \mathrm{m}^{-2}\right)^{-1}$ & $\begin{array}{l}\text { Absolute error in natural daylight is } \\
\pm 5 \% \text { maximum; } \pm 3 \% \text { typical }\end{array}$ & \multirow[t]{2}{*}{-40 to $65^{\circ} \mathrm{C}$} \\
\hline & LI 190SB & & & $\begin{array}{l}5 \mu \mathrm{A} \\
1000 \mu \text { moles s }^{-1} \mathrm{~m}^{-2}\end{array}$ & $\begin{array}{l}\text { Maximum deviation of } 1 \% \text { up to } \\
10000 \mu \text { moles s}^{-1} \mathrm{~m}^{-2}\end{array}$ & \\
\hline $\begin{array}{l}\text { Precision infrared ra- } \\
\text { diometer }\end{array}$ & $\begin{array}{l}\text { SI-111 } \\
\text { (IRR-P) }\end{array}$ & Surface temperature & ${ }^{\circ} \mathrm{C}$ & $\begin{array}{l} \pm 0.1^{\circ} \mathrm{C} @ \\
-10 \text { to } 65^{\circ} \mathrm{C} \\
\pm 0.3^{\circ} \mathrm{C} @ \\
-40 \text { to } 70^{\circ} \mathrm{C}\end{array}$ & $\begin{array}{l} \pm 0.2^{\circ} \mathrm{C} @-10 \text { to } 65^{\circ} \mathrm{C} \\
\text { (where target temperature is within } \\
20{ }^{\circ} \mathrm{C} \text { of sensor body temperature) } \\
\pm 0.5^{\circ} \mathrm{C} @-40 \text { to } 70{ }^{\circ} \mathrm{C} \\
\text { (where target temperature is }>20^{\circ} \mathrm{C} \\
\text { of sensor body temperature) }\end{array}$ & $\begin{array}{l}-55 \text { to } 80^{\circ} \mathrm{C} \\
0 \text { to } 100 \% \mathrm{RH}\end{array}$ \\
\hline
\end{tabular}

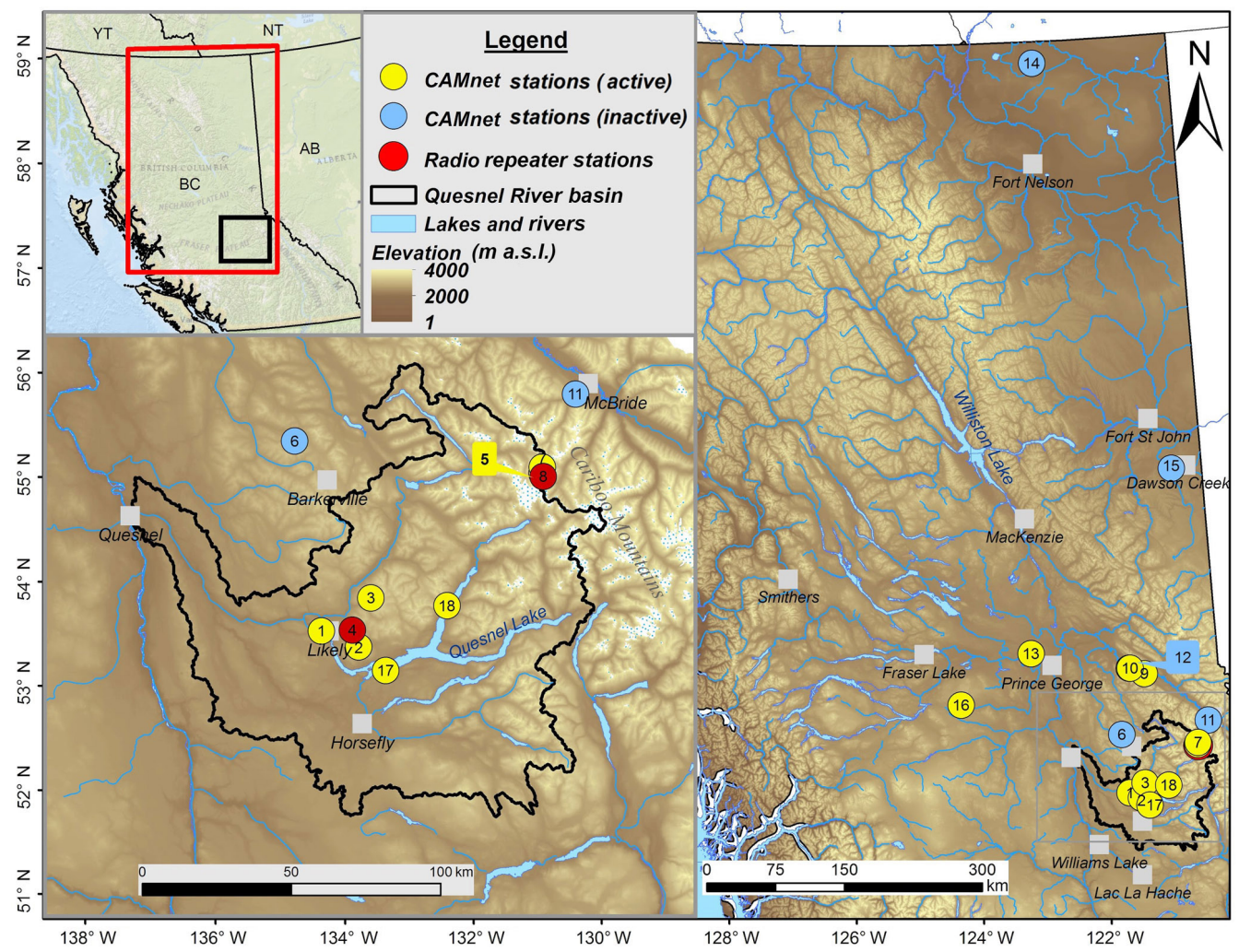

Figure 3. Map of north-central BC showing the location of active and inactive CAMnet weather and radio repeater stations, numbered as in Table 1.

Three additional weather stations mounted on $3 \mathrm{~m}$ tripods were also deployed during summer 2006 near Likely, BC, in an attempt to capture the effects of elevation gradients on atmospheric conditions in the Cariboo Mountains. Factors leading to the selection of Spanish, Browntop and Blackbear mountains as deployment sites included their range in elevations (1500-2000 m a.s.l.) and accessibility (deactivated forestry roads and/or hiking trails) and were within line of sight of each other, with one station being within line of sight of the QRRC. All were equipped with identical instrumentation to measure $2 \mathrm{~m}$ air temperature and relative humidity, $3 \mathrm{~m}$ wind speed and direction, atmospheric pressure, snow depth, rainfall and soil temperature at $10-15 \mathrm{~cm}$ in depth. Stations at Spanish and Blackbear mountains were installed 

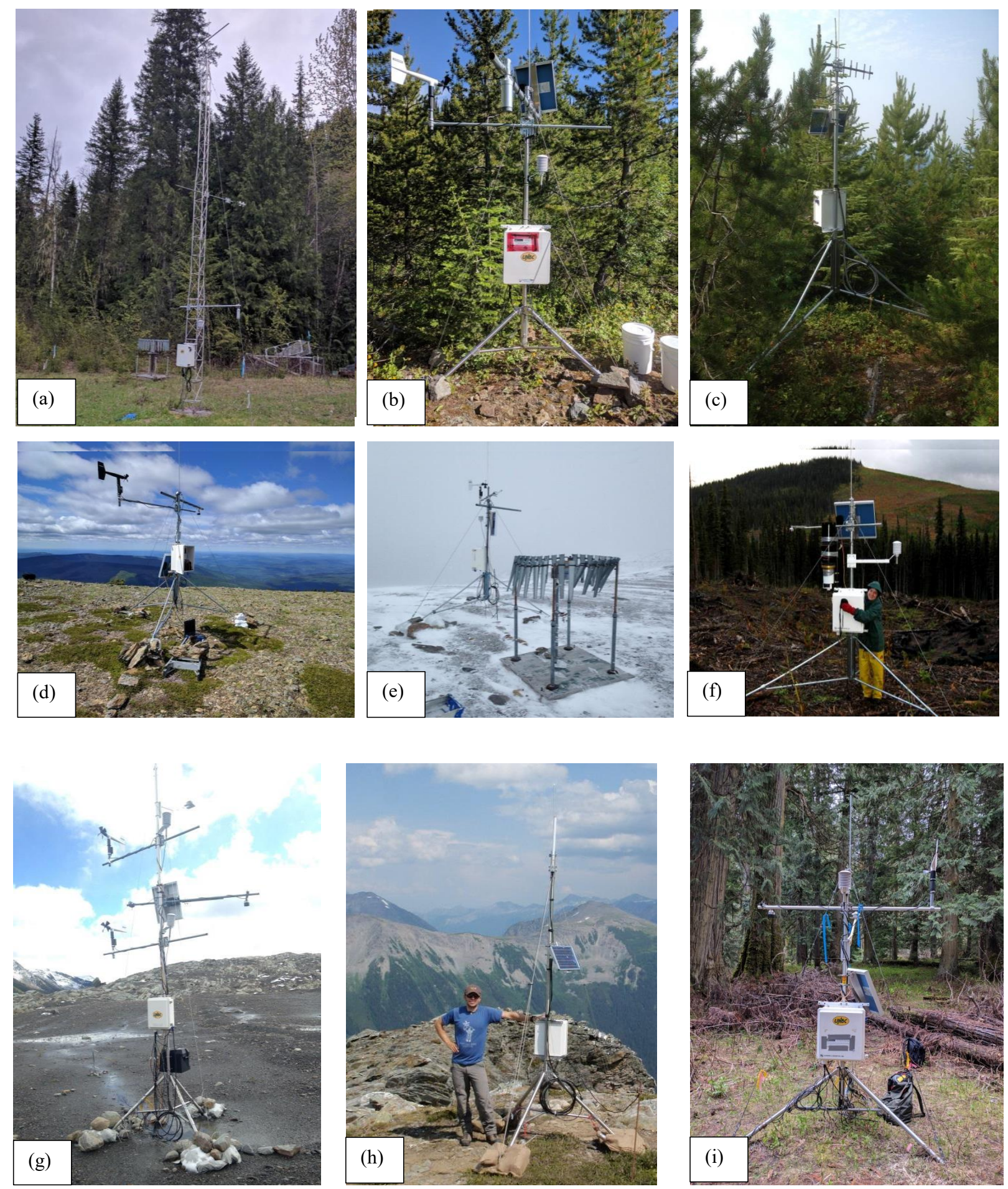

Figure 4. 

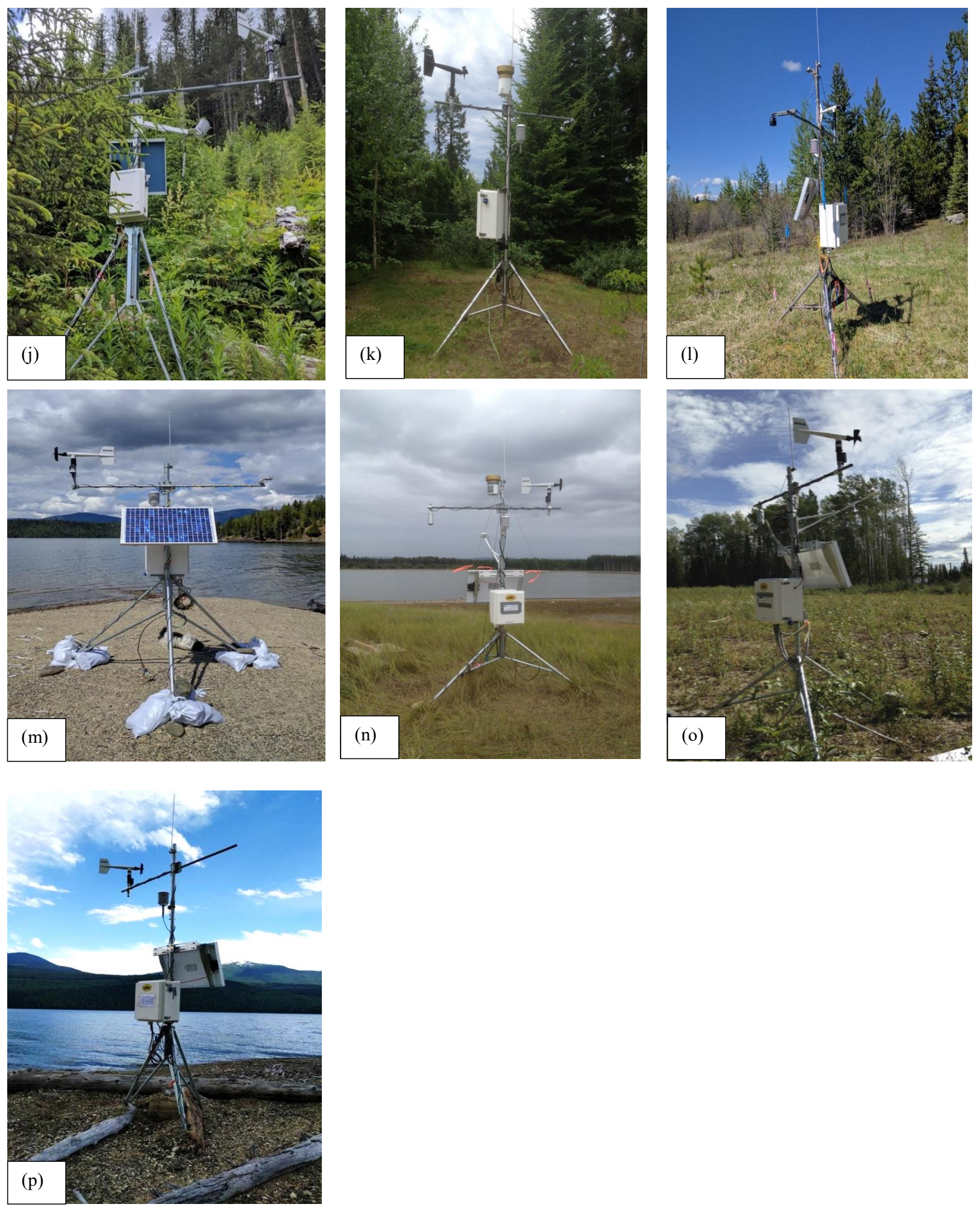

Figure 4. Photos of CAMnet weather stations: (a) QRRC in May 2017 (el. $743 \mathrm{~m}$ ), (b) Spanish Mountain in June 2017 (el. $1509 \mathrm{~m}$ ), (c) Blackbear Mountain radio repeater in July 2015 (el. 1509 m), (d) Browntop Mountain in June 2017 (el. 2030 m), (e) Upper Castle Creek Glacier in September 2015 (el. 2105 m), (f) Mount Tom in September 2008 (el. 1490 m), (g) Lower Castle Creek Glacier in September 2015 (el. 1803 m), (h) Castle Creek Glacier radio repeater in August 2009 (el. 2219 m), (i) Ancient Forest in May 2017 (el. 774 m), (j) Lunate Creek in June 2017 (el. 953 m), (k) Ness Lake in June 2015 (el. 763 m), (l) Tatuk Lake in May 2017 (el. 938 m), (m) Plato Point in May 2017 (el. 728), (n) Kiskatinaw in August 2015 (el. 726 m), (o) Coles Lake in July 2015 (el. 479 m) and (p) Long Creek in June 2017 (el. 728 m). 
in similar terrain (regenerating cutblocks of lodgepole pine stands) and elevations such that the meteorological conditions between the two exhibited little differences. As such, the meteorological instrumentation at Blackbear Mountain was decommissioned during the summer of 2007 but the radio repeater was retained to act as the communication hub between the remote Spanish and Browntop Mountain stations and the operational base computer. The Browntop Mountain weather station lies at $2030 \mathrm{~m}$ a.s.l. in the alpine terrain on an exposed ridge and endures excessive winds approaching $40 \mathrm{~m} \mathrm{~s}^{-1}$ in some storms. These high winds have been quite challenging in keeping the entire station operational, with the continuity of readings frequently disrupted through instrument damage (including the loss of multiple anemometers), icing and power malfunctions. A tipping bucket rain gauge was eventually dismantled on 11 July 2012 due to its low capacity to capture precipitation even when protected with an Alter shield. While a SR50 remains in operation at this site it rarely measures $>10 \mathrm{~cm}$ of snow as winds continually erode it from the ridge top towards the lee side of Browntop Mountain where massive snowdrifts form and persist during summer.

Equipment previously installed at Blackbear Mountain was moved during August 2007 to a bedrock ridge at $2105 \mathrm{~m}$ a.s.l. near Castle Creek Glacier, $40 \mathrm{~km}$ west of McBride, BC, to support research of the Western Canadian Cryospheric Network. Despite its exposed and remote location, the station has experienced only a few minor issues mainly from strong winds affecting precipitation measurements, with the loss on several occasions of the tipping bucket rain gauge's funnel and/or filter. A second weather station was installed at $1803 \mathrm{~m}$ a.s.l. in $2008, \sim 700 \mathrm{~m}$ in the Castle Creek Glacier forefield to complement the data being collected at higher elevation. The Lower Castle Creek Glacier weather station is unique in the CAMnet network in measuring air temperature, relative humidity, wind speed and direction at two heights $(4.1$ and $2.7 \mathrm{~m}$ ) above the surface on a $6 \mathrm{~m}$ mast, allowing estimates of turbulent sensible and latent heat fluxes. This site also contains an array of sensors to measure near-surface air or snow, skin surface and soil temperatures. A tipping bucket rain gauge protected by an Alter shield was added to the site on 21 August 2012. Both Castle Creek Glacier weather stations are within line of sight of a radio repeater mounted in August 2009 on a bedrock ridge at $2219 \mathrm{~m}$ a.s.l. facing eastward towards Castle Creek Valley. Combined, the two weather stations at Castle Creek Glacier provide a nearly continuous record of atmospheric and snow conditions exceeding a decade that complement well ongoing efforts to monitor the glacier's mass balance using push moraines, geodetic and remote sensing techniques.

A basic weather station was installed in 2007 for a period of 2 years at Mt. Tom, in the Cariboo Highlands near Wells and Barkerville, $\mathrm{BC}$, to support the research projects of two UNBC graduate students. This research was in collaboration with the BC Ministry of Forests, Lands, Natural Resource
Operations and Rural Development's (FLNRORD) Mt. Tom adaptive management trial. The spatial distribution of snow cover in forested and clear-cut areas of different sizes as well as soil moisture memory was the focus of these two projects. Weekly snow survey data during one ablation season in addition to snow/surface temperatures were collected during this experiment.

Following the completion of the two graduate student projects at Mt. Tom, the equipment was transferred in October 2009 to a site at the Ancient Forest $\sim 100 \mathrm{~km}$ east of Prince George at an elevation of $775 \mathrm{~m}$ a.s.l. The station was installed a few hundred metres from the Yellowhead Highway in a small clearing in the inland temperate rainforest situated on the northwestern border of the Cariboo Mountains (Stevenson et al., 2011), now within the boundary of the Ancient Forest/Chun T'oh Whudujut Provincial Park created in 2016. The damp, low-lying characteristics of this old-growth forest limit sky visibility and expose the site to abundant precipitation in all seasons with heavy snowfall during winter. Ground cover vegetation consists of large ferns, tall grasses and dense Devil's club. Measurements at this site include soil moisture at three depths down to $65 \mathrm{~cm}$. The CR10X data logger at this site was replaced with a CR1000 in August 2013, while the tripod and a cross arm were replaced in $\mathrm{Au}-$ gust 2015 following a near-direct hit by a felled old-growth western redcedar. This station provides critical information on BC's great "snowforest" in a changing climate including support for ongoing ecosystem, ecological and outdoor recreation and tourism research at UNBC. It also serves routinely as a field site for a snow survey conducted by UNBC students enrolled in a course titled "Snow and Ice".

In proximity to the Ancient Forest, a basic meteorological station at Lunate Creek was acquired from the BC Ministry of FLNRORD in May 2010. The equipment at the station was fully updated and deployed in a regenerating western redcedar and hemlock cutblock at an elevation of $953 \mathrm{~m}$ a.s.l. The tower sits on a $20^{\circ}$ north-facing slope overlooking the Rocky Mountain Trench. Owing to bear and rodent activity along with the minimal incoming solar radiation during winter this site has experienced periodic power interruptions and thus suffers extended data gaps. A second weather station was installed on a neighbouring cutblock at $1134 \mathrm{~m}$ a.s.l. to monitor upslope conditions during a period of 1 year in support of a graduate student project that quantified the contribution of snowmelt to soil moisture replenishment on the area's steep inclines. The toe slopes of the Cariboo Mountains are well known for their abundant soil moisture and springs even during dry summer periods, with these water resources vital in sustaining the Ancient Forest's old-growth forest stands.

Similarly to the Lunate Creek site, another weather station was acquired from BC Ministry of FLNRORD in July 2010 at Lucille Mountain, west of McBride, BC. The weather station is deployed in a regenerating cutblock (planted) at an elevation of 1587 ma.s.l. and faces the Rocky Mountain 
Trench. Due to its difficult access and animal activity, the station has not been visited nor maintained since 2013 .

Following the conclusion of the intensive field campaign at Lunate Creek, its upper station was transferred in July 2012 to Ness Lake, $\sim 35 \mathrm{~km}$ northwest of UNBC on the property of the senior and corresponding author. The weather station lies $\sim 25 \mathrm{~m}$ from the eastern shore of Ness Lake at an elevation of $763 \mathrm{~m}$ a.s.l. The tower has only $\sim 75 \%$ sky visibility since it is deployed in an area with large Douglas firs and two nearby residences. Data collected contribute to studying the effects that public recreational use has on Ness Lake wave activity and shoreline erosion. This site also serves to train students and research staff on the use of the meteorological equipment; testing new, damaged or repaired equipment; and data logger programming and has also provided meteorological resources for UNBC courses. This site benefits from access to $\mathrm{AC}$ power and the internet, facilitating automatic data transfers to a computer server at UNBC.

To support a graduate student's project investigating the water balance of a small boreal lake and its watershed, a weather station was deployed at Coles Lake, $\sim 100 \mathrm{~km}$ north of Fort Nelson, BC, near the border to the Northwest Territories in June 2013. The weather station resided $\sim 500 \mathrm{~m}$ north of Coles Lake on the property of Quicksilver Inc., an oil and gas extraction company that, along with the BC Ministry of FLNRORD, supported the research. Apart from the meteorological data collected at the weather station, ancillary data included rainfall at three additional sites under various vegetation canopies, snow depth and snow water equivalent through biweekly snow surveys at three sites during one ablation season, Coles Lake inflows and outflows, shallow groundwater levels with three piezometer nests along the lakeshore and lake skin surface water temperature.

Completion of the field campaign at Coles Lake allowed its station to be moved to the Kiskatinaw watershed in the summer of 2015. The site was located $300 \mathrm{~m}$ south of Arras Road and the John Hart Highway, $\sim 19 \mathrm{~km}$ west of Dawson Creek, BC. The tower was installed in a $\sim 4000 \mathrm{~m}^{2}$ opening atop a small hill $\sim 60 \mathrm{~m}$ north of the Hansen Reservoir. Ground cover consisted of unmaintained grass and the surrounding area is composed of mixed deciduous-coniferous trees and agricultural plots. Data for this station supported a graduate student's study on the prediction of the spring freshet in the Kiskatinaw River that supplies domestic, commercial and industrial water for Dawson Creek and surrounding communities.

In a continuing effort to improve and integrate knowledge on the Nechako River (a major tributary to the Fraser River) and its watershed, a weather station was deployed at Tatuk Lake, BC, in September 2015. The weather station stands $\sim 250 \mathrm{~m}$ from the northern shore of Tatuk Lake in the headwaters of the Chilako River, $\sim 75 \mathrm{~km}$ south of Vanderhoof, BC. It resides on the Tatuk Lake Resort's private property, which provides safe and secure year-round access. The tower sits at an elevation of $938 \mathrm{~m}$ a.s.1. in an open sec- tion $\left(\sim 1000 \mathrm{~m}^{2}\right)$ where there is $\sim 85 \%$ sky visibility. Tall grasses, shrubs and rocky soil characterize the site. This station also serves as a reliable source of meteorological information for local communities of the Nechako watershed and as a demonstration site for local elementary and middle school students.

The catastrophic failure of a tailings pond impoundment at Mount Polley mine near Likely, BC, in August 2014 (Petticrew et al., 2015) renewed interest in monitoring closely atmospheric conditions at Quesnel Lake and the surrounding area. While CAMnet included three weather stations near Likely, none was located on the shores of Quesnel Lake. To fill this observational gap, two lake-level sites were chosen for weather station deployment in August 2016 and 2017. The Plato Point weather station is located $22 \mathrm{~km}$ southeast of Likely on the sandy shoreline of Quesnel Lake just east of the Plato Island Resort. The tower sits at an elevation of 728 ma.s.l. and has $\sim 90 \%$ sky visibility. The station has excellent exposure in all cardinal directions except towards the south, allowing measurement of long-fetch winds aligned along the principal axis of Quesnel Lake's main basin. During spring snowmelt, water levels rise, partially submerging the station. Two additional probes measure water and nearsurface air temperatures. In the summer of 2017, the equipment from the Kiskatinaw watershed weather station was moved to Long Creek, on a gravel beach along the shoreline of Quesnel Lake approximately halfway up its north arm. The tower is deployed at an elevation of $728 \mathrm{~m}$ a.s.l. and has $\sim 75 \%$ sky visibility. Small shrubs and mature conifers flank the western side of the station that otherwise benefits from excellent exposure in all other cardinal directions. Both the Plato Point and Long Creek weather stations allow detection of wind storms that generate basin-scale hydrodynamic processes in Quesnel Lake, leading to possible resuspension of mine tailings sediments deposited on the lake bottom during the 2014 spill.

\subsection{Equipment used at each site}

The majority of the meteorological equipment was purchased from Campbell Scientific Canada (CSC) and its suppliers; however, this report should not be construed as an endorsement of their products. Sole use of CSC equipment at nearly all CAMnet sites facilitates data cross comparisons, equipment substitutions, student and research staff training, and ensures the homogeneity of the hydrometeorological records (see Sect. 5.2). Most remote stations are assembled on $3 \mathrm{~m}$ tripods (i.e., CM110 or UT10) anchored to the ground to maintain the orientation of the tower, ensure proper positioning of sensors and prevent electrical damage from lightning strikes. Most of the sensors are installed and configured as recommended in the manuals (e.g., anemometers $\sim 3 \mathrm{~m}$ above the ground surface and the air temperature and humidity sensors $\sim 2 \mathrm{~m}$ above the ground surface). However, the precipitation gauges were an exception since the construc- 
tion of concrete footings was not feasible at the remote sites. Instead, the precipitation gauges were typically installed on $1.2 \mathrm{~m} \times 1.2 \mathrm{~m}$ platforms anchored to the ground with rebar to support and level the rain gauges as well as the Alter wind screens that reduce the effects of wind and turbulence on precipitation measurements. Most of the remote stations employ CR1000 data loggers from CSC to power and operate the sensors. A CR23X data logger is used at the QRRC station to run the sensors as it can provide the necessary power to engage the CNR1 net radiometer heater. Supplement Table S1 provides a detailed summary of the equipment and sensors used at each CAMnet station.

\subsection{Precision and accuracy of the instrumentation}

Table 2 provides the specifications, including precision and sensitivity, for sensors used at each CAMnet station. These sensors are manufactured to withstand strong variations in environmental conditions and often remain unattended for lengthy periods of time. Most of the instruments, including the tipping bucket rain gauges, barometers and wind monitors, are initially calibrated and come with a certificate of accuracy. Depending on the amount of usage and the presence of adverse atmospheric conditions, some of the CAMnet instrumentation undergoes periodic recalibration, as maintaining the precision and quality of data remains of utmost importance to the development of the database. Recalibration and regular maintenance are completed if the quality of the data being sampled starts to become affected or if there is obvious damage to the instrumentation. Common errors in sampling precision and accuracy stem from worn-out equipment such as the depth-to-target data recorded by the SR50 ultrasonic depth sensor that can contain outlying values when the transducer wears out. This causes peaks in the depth-to-target data that are carried over to the snow depth data through calculations. These peaks can be filtered out relatively easily so they do not significantly affect data quality.

All instrumentation used at CAMnet weather stations includes a recommended temperature operating range where data collected outside these parameters are subject to larger errors. However, these operating ranges are quite vast (typically -40 to $+70^{\circ} \mathrm{C}$ ), thus minimizing potential errors. Note that data loggers with extended temperature operating ranges are employed at all CAMnet sites given the frigid conditions often encountered during winter in the Cariboo Mountains and surrounding area. Snow and ice, like temperature, have the ability to affect the precision of the data and accuracy of the equipment. Rime build-up can cause the anemometer blades to freeze up, resulting in extended periods of data with wind speeds of $0 \mathrm{~m} \mathrm{~s}^{-1}$. Snow accumulation on pyranometers and the radiation shields of temperature and relative humidity probes can also affect the precision of the sampled data. Regular site visits mitigate these issues and allow for periodic instrument check-ups to maintain the quality of the data.

\section{Data collection}

\subsection{Frequency}

Data loggers were programmed using the Loggernet SCWin, CRBasic and Edlog software from CSC. All of the station programs employ scan intervals of $1 \mathrm{~min}$ and data intervals of $15 \mathrm{~min}$. Depending on the sensors and the specific variable being measured, sampling either occurs once every $15 \mathrm{~min}$ or is measured for the entire data interval and averaged. Some of the measurements are also simply summed over the $15 \mathrm{~min}$ period, such as precipitation and incoming solar radiation. Regardless of the sampling interval, all collected data are stored in $15 \mathrm{~min}$ timestamps in the data logger memory and the database spreadsheets.

All CAMnet weather stations are visited at least once annually for data downloads and maintenance, although repeat visits are not feasible at the most remote sites (i.e., Upper and Lower Castle Creek Glacier weather stations) given access is often by helicopter. All other sites, however, are usually visited two to four times a year, while others such as the Quesnel River Research Centre (QRRC) and Ness Lake are easily accessible and thus serviced much more regularly. The frequency of visits escalates during intensive field campaigns in association with a student's research project or accelerated to address promptly a known technical or instrumental issue.

\subsection{Automated data transfers}

Spread-spectrum radios facilitate communication and automated data transfers between the weather stations at Spanish Mountain, Browntop Mountain and Blackbear Mountain (no longer equipped with meteorological equipment) with the operational base computer. Spread-spectrum radios have a range of $\sim 20 \mathrm{~km}$ within line of sight (Campbell Scientific, 2017); however, obstructions such as hills and vegetation attenuate significantly the radio signals while the specific type of antenna used modulates signal strength. Thus, a radio signal range of $\sim 13 \mathrm{~km}$ was chosen during the site selection process for stations 1-4 (Table 1). The Blackbear Mountain radio repeater routes radio communication from the Spanish Mountain and Browntop Mountain stations once daily to the QRRC operational base computer that acts as a gateway to online data retrieval. Radio communication from the QRRC weather station to this computer occurs on an hourly basis, allowing online data transfers to a computer server on the UNBC campus in Prince George, BC, for web-based visualization and long-term archiving.

A second radio repeater station installed on a bedrock ridge at Castle Creek Glacier within line of sight of the two nearby weather stations and the Castle Creek Valley allowed remote data downloads at the end of a deactivated forestry road accessed by a $4 \times 4$ vehicle. A major landslide in 2012 , however, has since blocked road access to the upper reaches of the Castle Creek Valley, rendering this radio repeater obso- 
lete. Thus, the radio repeater station at Castle Creek Glacier may soon be relocated to a site near Quesnel Lake to extend remote communication at sites there.

\subsection{Gaps and infilling}

Some time series within the database have gaps (Fig. 5) either for entire stations or individual instruments and for a variety of reasons. Stations based in wilderness settings have experienced interruptions due to environmental factors such as falling trees, intense storms and wintertime icing (see ECCC, 2015). Less common, but potentially more destructive to the equipment and instrumentation, are the wildlife interactions, particularly with large mammals such as black and grizzly bears. Since the NHG's research requires long-term historical climate records, it is necessary to find other resources that may fill some of the data gaps. A few meteorological stations exist in the vicinity of the Quesnel River basin that may be able to provide additional data to complete this record (Fig. 2). Specifically, the BC Ministry of FLNRORD Likely Aerodrome weather station $\left(52^{\circ} 36^{\prime} 05^{\prime \prime} \mathrm{N}, 121^{\circ} 30^{\prime} 48^{\prime \prime} \mathrm{W}\right.$; elevation $1046 \mathrm{~m}$ a.s.1.), the BC Ministry of Environment snow pillows at Yanks Peak East $\left(52^{\circ} 49^{\prime} \mathrm{N}, 121^{\circ} 21^{\prime} \mathrm{W}\right.$; elevation $1683 \mathrm{~m}$ a.s.l.) and Barkerville $\left(53^{\circ} 03^{\prime} \mathrm{N}, 121^{\circ} 29^{\prime} \mathrm{W}\right.$; elevation $1520 \mathrm{~m}$ a.s.1.), and the Environment and Climate Change Canada (ECCC) Barkerville weather station ( $53^{\circ} 04^{\prime} 09^{\prime \prime} \mathrm{N}$, $121^{\circ} 30^{\prime} 53^{\prime \prime} \mathrm{W}$; elevation $1283 \mathrm{~m}$ a.s.l.) have reliable and relatively long-term meteorological measurements for the Cariboo Mountains and in the vicinity of CAMnet weather stations. Note that the ECCC Barkerville record begins in 1888, making it BC's third longest observation-based meteorological dataset; however, this remains a weather station operated by volunteers, rendering data quality and homogeneity suspect at times. Nonetheless, these proximal weather and snow pillow stations provide valuable data on hydrometeorological conditions when CAMnet stations experienced data gaps. CAMnet stations are notably deficient in measuring cold season precipitation and snow water equivalence, variables that may be acquired from these additional weather stations.

Temporal gaps at one CAMnet station may also be infilled with data from another proximal one in the network. For instance, daily air temperatures for the QRRC, Spanish Mountain and Browntop Mountain weather stations are highly correlated ( $r \geq 0.92$; Sharma, 2014). The local surface air temperature lapse rates vary from month to month with the steepest rates $\left(6.6^{\circ} \mathrm{C} \mathrm{km}^{-1}\right)$ during summer and with more modest levels during winter $\left(2.7^{\circ} \mathrm{C} \mathrm{km}^{-1}\right)$ (Sharma, 2014). Indeed, potent air temperature inversions often arise in winter such that care must be exercised in reconstructing this variable. Vigorous orographic enhancement of precipitation occurs in the Cariboo Mountains inducing strong precipitation gradients across their steep elevation gradients. Thus, sitespecific conditions such as altitude, exposure, and land and vegetation cover induce considerable spatial variations in all quantities measured at CAMnet weather stations that require special attention in reconstructing missing data.

\subsection{Data quality assessment and control}

For CAMnet observed data, quality assessment is carried out for individual parameters at each station through statistical quality control procedures, analysis of frequency intervals, values, manual observations, etc. The CAMnet database consists of the original raw data allowing users to manipulate them according to their needs and desires. Missing timestamps are identified and filled with "NA" using codes developed in R (R Core Team, 2014) to maintain a complete yearly data record for each station. All data values assessed as erroneous, extreme or outside a predetermined frequency interval are simply flagged (highlighted in yellow) and recorded in the metadata documentation. Data from several sampled variables are also assessed for their quality through visual inspection and scatter plots such as snow depth and soil temperature. An outline of this quality assessment and control techniques can be found in a document located in the online database in each of the station's respective folders.

A particular concern with data quality is precipitation measurements in cold, windy environments such as the Cariboo Mountains. Apart from the freezing of tipping bucket rain gauges, high winds, evaporative losses and trace events are factors that often induce errors in precipitation measurements, especially for snowfall (Cherry et al., 2005). CAMnet data are not immune to inaccuracies due to precipitation measurement errors; however, the installation of single Alter shields at most of the CAMnet weather stations with tipping bucket rain gauges reduces the effects of wind undercatch of precipitation. Similarly to other CAMnet measurements, no modifications are performed on the precipitation data to correct for possible wind undercatch given the various strategies reported in the literature to address this (e.g., Sevruk, 1982). A few of the tipping bucket precipitation gauges at other CAMnet weather stations (most notably the Ancient Forest and Spanish Mountain sites) are equipped seasonally with CS705 snowfall adapters that are filled with antifreeze to melt and record solid precipitation. However, the antifreeze remains prone to dilution from precipitation and hence often freezes up, particularly during midwinter when air temperatures may reach $\leq-30^{\circ} \mathrm{C}$. Despite their known limitations, the tipping bucket rain gauges provide reasonable (liquid) precipitation records for the Cariboo Mountains and surrounding areas (see Sect. 4.6). Indeed, the accuracy of the CAMnet precipitation measurements remains comparable to that measured at nearby weather stations that meet WMO standards (Hay, 2018). 


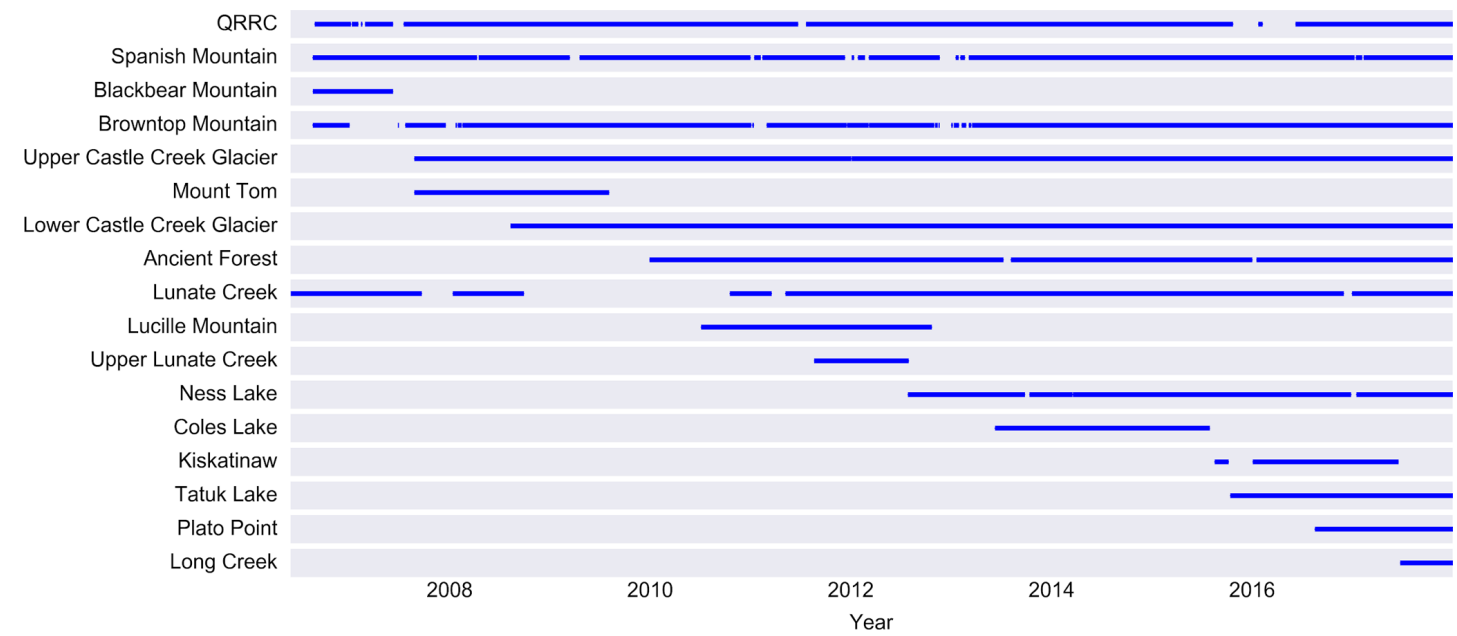

Figure 5. Operating periods for active and inactive CAMnet weather stations (1 January 2006-31 December 2017), deduced by analyzing the battery voltage required to power each station's data logger and instruments. Gaps in datasets occur due to a variety of reasons outlined in Sect. 5.1. Note that data may not be available for all instruments even when a station is operational (e.g., the icing of anemometers during winter).

\subsection{Metadata}

Metadata for each climate station in the CAMnet network are important to take into consideration when utilizing the associated data and are therefore summarized in a detailed .docx file. This document, a copy of which is available with the data for each station, outlines site location (coordinates, elevation, etc.) and access and provides a brief overview of the landscape, station equipment specifics (e.g., instrument heights) and data collection parameters.

Field notes and site logs are documented using a mediawiki.org web page allowing the ability to check on historical station visits dating back to the original deployment. These logs remain particularly valuable due to the high turnover of students and research staff in the NHG (e.g., summer field assistants) and serve as a complete and detailed resource. Weather conditions and equipment status, as well as work carried out, comprise important factors noted during each station visit and are therefore documented in these logs. Moreover, instrument serial numbers, recalibration and servicing schedules as well as an ongoing to-do list of field work activities are systematically updated on the CAMnet wiki.

\subsection{Example data}

CAMnet data compare favourably with measurements from independent meteorological networks that meet WMO standards such as those collected by Environment and Climate Change Canada and the BC Ministry of FLNRORD or with gridded climate products such as ANUSPLIN (McKenney et al., 2011). For example, monthly air temperature and precipitation collected at the BC Ministry of FLNRORD Likely Aerodrome weather station $\left(52^{\circ} 36^{\prime} 54^{\prime \prime} \mathrm{N}, 121^{\circ} 30^{\prime} 48^{\prime \prime} \mathrm{W}\right.$; elevation $1046 \mathrm{~m}$ a.s.l.) correspond well with data from the
CAMnet QRRC weather station $5.2 \mathrm{~km}$ away with differences of only $0.45^{\circ} \mathrm{C}$ and $22 \%(117 \mathrm{~mm})$ during 2014, respectively (Figs. S1 and S2). Furthermore, profiles of air temperature and precipitation along a transect crossing the Cariboo Mountains between Williams Lake and McBride, BC, based on 1950-2010 ANUSPLIN data, reveal the expected cooler, wetter conditions at higher elevations (Fig. 6). Climatological data from proximal CAMnet stations to this transect match well the ANUSPLIN data, with differences explained partly by the altitudes of the in situ data relative to the smoothed topography of the gridded climate product. The QRRC, Spanish Mountain, Browntop Mountain and Upper Castle Creek Glacier stations exhibit strong elevational dependence in rainfall amounts, albeit with an appreciable precipitation undercatch relative to ANUSPLIN (Fig. 6a). Air temperatures at CAMnet stations cool from $\sim 4{ }^{\circ} \mathrm{C}$ at the QRRC's valley bottom site to near $-1{ }^{\circ} \mathrm{C}$ in the alpine settings of Browntop Mountain and the Upper and Lower Castle Creek stations, in close agreement with the gridded climate data (Fig. 6b).

CAMnet data remain central to the NHG's goal of investigating the meteorological drivers influencing the hydrology of north-central BC. Indeed, CAMnet allows monitoring the antecedent and real-time conditions of hydrological extremes including droughts and floods, as experienced in the region during 2010 and 2011, respectively (Fig. 7). In late winterearly spring 2010, shallow snow depths (maximum of $45 \mathrm{~cm}$ ) followed by a hot, dry summer during an El Niño event led to scant total annual precipitation $(346 \mathrm{~mm}), 36 \%$ lower than the decadal mean observed at the QRRC weather station. This yielded some of the lowest annual discharge rates ever recorded for the Quesnel River (Déry et al., 2012). These dry conditions were followed by a much deeper snowpack (peak 

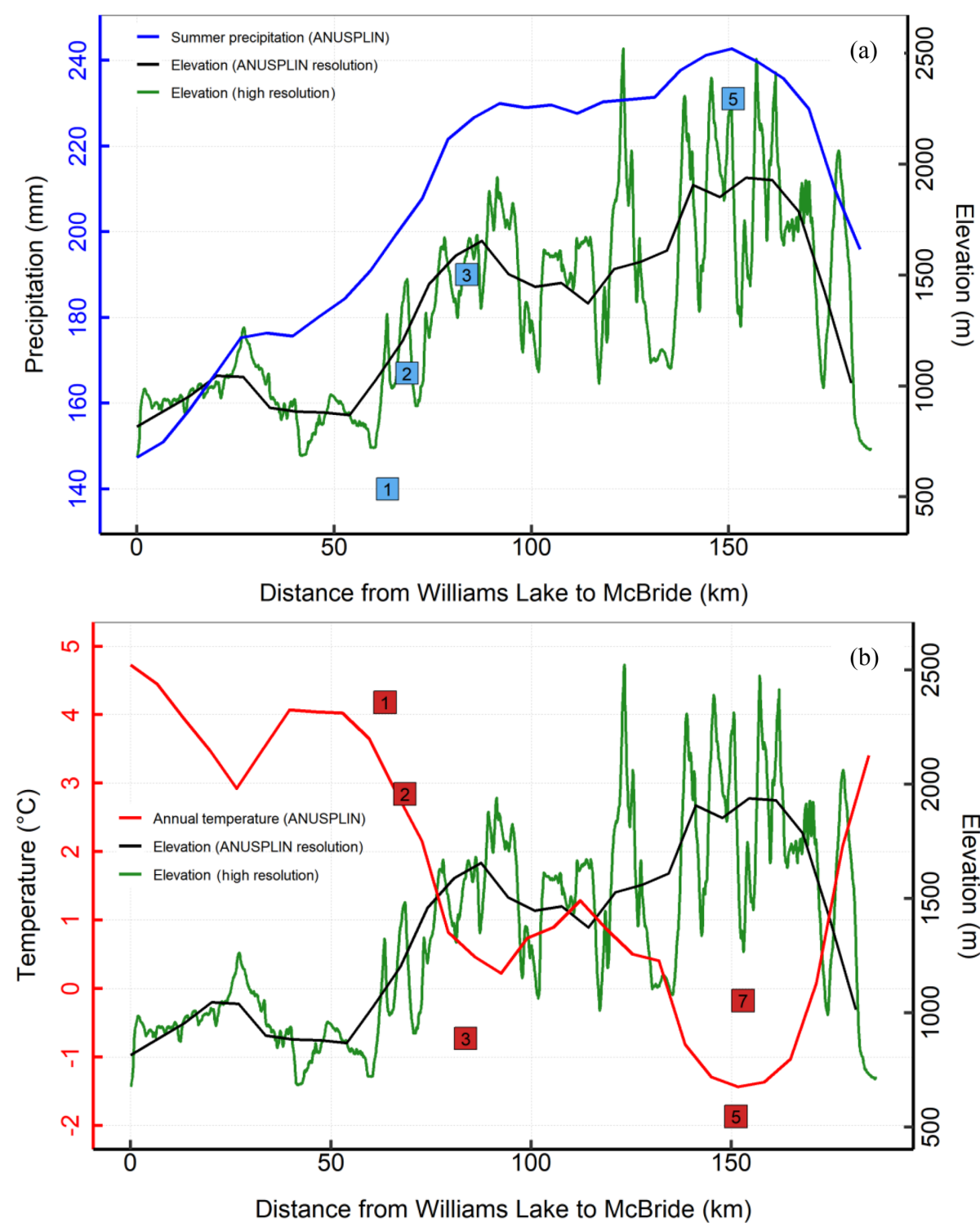

Figure 6. Profiles of average (a) total summer precipitation and (b) annual air temperature along an elevational transect (as shown in Fig. 2) from Williams Lake to McBride, BC, based on the 1950-2010 ANUSPLIN gridded product along with CAMnet weather station data. Elevations at high spatial resolution $(\sim 90 \mathrm{~m})$ and of the ANUSPLIN smoothed topography (at a spatial resolution of $\sim 10 \mathrm{~km})$ are shown. Squares depict climatological results for CAMnet stations in proximity to the transect and are numbered as in Table 1. Results for CAMnet stations depend on data availability as follows: (1) QRRC (2007-2017), (2) Spanish Mountain (2007-2017), (3) Browntop Mountain (20072017), (5) Upper Castle Creek Glacier (2008-2017) and (7) Lower Castle Creek Glacier (2009-2016).

snow depth of $114 \mathrm{~cm}$ ) in winter-spring of 2011 with precipitation during the first half of $2011(322 \mathrm{~mm})$ nearly equating the total for 2010. These meteorological conditions led to saturated soils, increased overland flow and elevated river runoff throughout 2011.

\section{Challenges and opportunities}

\subsection{Physical and environmental challenges}

The construction and maintenance of a highly sensitive, longterm database such as CAMnet generates distinct challenges on a variety of scales. Power outages due to battery failure or solar panel issues are a major contributor towards data loss and interruptions in sampling (see Sect. 4.3), a risk that is elevated during winter when snow and ice may cover solar panels and immerse instrumentation while cold tempera- 


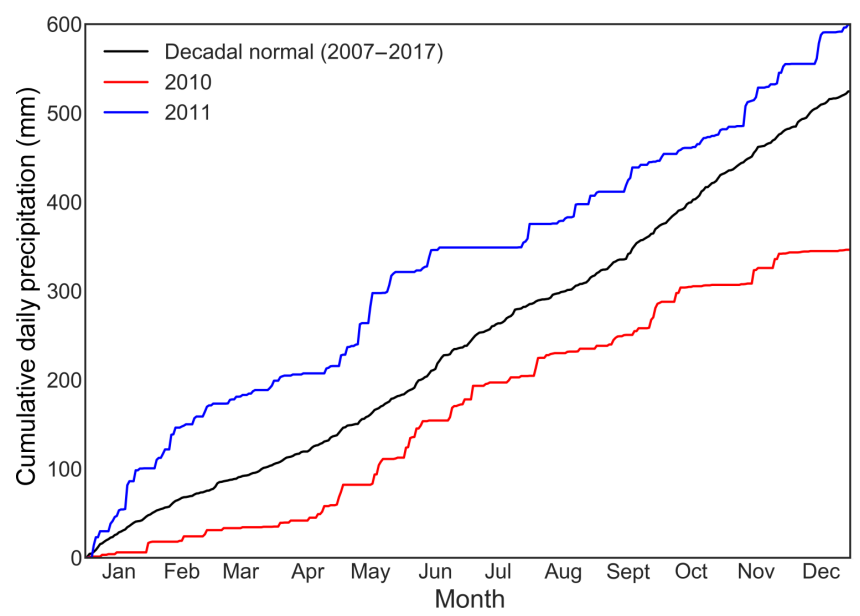

Figure 7. Cumulative daily precipitation recorded at the QRRC CAMnet station (using a heated Ogawa Seiki tipping bucket rain gauge) for 2010, 2011 and the overall mean for 2007-2017.

tures may accelerate the depletion of batteries. CAMnet stations have also been plagued with several animal incidents whereby the equipment has been displaced, damaged or rendered inoperable. Additionally, wildlife also has the ability to influence data solely by its presence, with snowpack measurements that rely on an undisturbed section of snow beneath the sensor being especially vulnerable. Other environmental considerations include lightning strikes that are mitigated by robustly grounding each station and the risk of damage from wildfires, which were extensive throughout the Cariboo region during the summer of 2017 and led to ashfall in nearby precipitation gauges. Physical challenges are presented by the complex terrain and remote locations of many stations, which also preclude frequent site visits; some stations such as those situated near Castle Creek Glacier are only visited once per year. Methods to access station sites include the following: through the use of a $4 \times 4$ vehicle (often on deactivated logging roads), a helicopter, a snowmobile and on foot (hiking in summer, snowshoeing in winter). Since these remote locations and environments are fundamental for local and regional hydrology, the importance for hydrometeorological data collection and the CAMnet network is pronounced; however, difficulty associated with securing funds to sustain this extensive network of remote weather stations (e.g., costs associated with field work and travel, equipment repairs, recalibration and purchases, student and research staff wages) remains a distinct and ongoing challenge.

\subsection{Data homogeneity challenges}

To minimize possible spurious trends or step changes in the hydrometeorological observations, all CAMnet sites are inspected and maintained regularly with faulty instrumentation repaired or replaced as necessary. While dedicated efforts are made in substituting deficient equipment with the same make and model, this is not always feasible if, for instance, the supplier no longer fabricates a given piece of equipment or specific model. Meteorological towers may shift under the influence of winds, frost heaving and heavy snowpacks, altering the measurement heights and possibly rendering the station unlevelled. Modifications to data logger programs (e.g., to switch on or off the heater for the QRRC radiometer) or operating systems may induce additional discontinuities in the CAMnet data.

Despite efforts to maintain consistency in the CAMnet datasets by routine station inspection and maintenance, various factors have resulted in a small fraction of data being influenced by external factors. Examples of these include the encroaching vegetation around the station on Spanish Mountain, the accidental rotation of the Browntop wind vane (away from north), and the replacement of instruments and equipment after various wildlife incidents and severe storms. As with data gaps, no post-processing of the data has been performed to assess their homogeneity, to remove suspect trends or erroneous data points. Site photos, field notes and post-trip updates of metadata remain invaluable resources in resolving issues related to these external influences and are available for any parties utilizing CAMnet data.

\subsection{Opportunistic measurements}

A primary objective of CAMnet remains to develop longterm hydrometeorological records in the poorly sampled Cariboo Mountains to assess climate change impacts on regional snow, glacier and water resources. This requires longterm homogeneous records of hydrometeorological conditions in the Cariboo Mountains at strategic locations such as the QRRC, Browntop and Spanish Mountains, and Castle Creek Glacier. A broader role of this long-term monitoring is the ability to answer unforeseen questions or research needs such as wildfires, pest infestations, mine spills (such as the Mount Polley mine accident), future resource extraction and land use and cover change in the area in addition to climate change. Indeed, CAMnet may assist in answering questions that have not yet been asked or even contemplated while providing baseline data in the event of future disturbances. Pushing CAMnet data online in (near-)real time also allows monitoring current atmospheric conditions remotely to assist in mitigating extreme events such as atmospheric rivers, floods or intense convective storms that can ignite wildfires such as in July 2017 in the BC interior. Finally, the mobile nature of the $3 \mathrm{~m}$ masts facilitates the transport and rapid deployment of weather stations to various sites, often to support a graduate student's research project or an intensive field campaign at a designated site. 


\subsection{Research, training and educational opportunities}

CAMnet now assembles over a decade of sub-hourly hydrometeorological observations in the Cariboo Mountains and the surrounding area, forming the core data for multiple undergraduate and graduate student projects at UNBC and other institutions. It allows for training opportunities for students and research staff to develop skills in deploying meteorological instruments, data logger programming, data quality control and interpretation, as well as field expertise in remote terrain. CAMnet data and site photos are routinely used in undergraduate and graduate level courses to demonstrate regional examples of phenomena studied in class. CAMnet weather stations also provide staging sites for educational videos (e.g., for the Vancouver Aquarium's Year of Science series), for media interviews and for outreach activities for students of all levels. Finally, CAMnet provides opportunities to undertake interdisciplinary research at UNBC and institutions across Canada and abroad.

\section{Ancillary data}

Other studies focused on the Cariboo Mountains and surrounding area have generated ample ancillary data to the CAMnet hydrometeorological records. This includes an ongoing effort to collect seasonal and annual mass balance measurements at Castle Creek Glacier initiated in 2008 by colleagues at UNBC. This site is of particular interest given its record of annual push moraines, allowing a reconstruction of the glacier's retreat since the mid-1940s (Beedle et al., 2009). Eddy covariance measurements of turbulent fluxes on Castle Creek Glacier were also conducted during two summer field campaigns (in 2010 and 2012), during which additional atmospheric measurements were collected on the glacier (Radić et al., 2017). Sediment fluxes in Castle Creek and its main tributaries were also sampled during two other summer field campaigns (in 2008 and 2011; Leggat et al., 2015; Stott et al., 2016). Meteorological observations along the shores of Quesnel Lake support ongoing efforts to understand the long-term impacts of the Mount Polley mine tailings pond spill on the water quality and ecology of the system (Petticrew et al., 2015). A dedicated effort, based at the QRRC, is being made to monitor lake conditions (e.g., vertical profiles of water temperature, electrical conductivity, turbidity), as well as downstream water quality, temperature, and sediment concentrations and quality in the Quesnel River. This ongoing project benefits from historical, background data collected on Quesnel Lake starting in the early 2000s (Laval et al., 2008). Finally, provincial and federal networks operate additional meteorological and snow pillow stations while the Water Survey of Canada manages several hydrometric gauging stations on the main waterways draining the Cariboo Mountains including the Fraser, North Thompson, Clearwater, Quesnel, Horsefly, Doré, Willow and Bowron rivers (see Fig. 2 and Déry et al., 2012). This as- semblage of unique ecosystems in pristine landscapes, availability of existing hydrometeorological data and a reliable research station to base field activities make the Cariboo Mountains particularly attractive for ongoing environmental and ecological research.

\section{Recent and future expansion and application of CAMnet}

During the summer of 2018, three additional meteorological stations were deployed along the shores of Quesnel Lake in support of an ongoing project investigating its resiliency to the Mount Polley mine tailings impoundment breach. Quesnel Lake has a complex morphometry with the steep surrounding topography often channelling winds. The area is also susceptible to mountain-valley circulations during clear summer days, with katabatic winds descending the steep, glacierized and snow-covered slopes towards the lower reaches of the valleys. Concerns over resuspension of lake-bottom sediments deposited during the tailings pond breach associated with wind-driven seiches require improved monitoring of atmospheric conditions including winds along Quesnel Lake.

In support of a new project titled the Storms and Precipitation Across the continental Divide Experiment (SPADE), a CAMnet weather station will be deployed near or within Kootenay National Park in southeastern BC during the fall of 2018. This will complement an existing array of meteorological stations operated by the University of Saskatchewan's Coldwater Laboratory at Fortress Mountain and Marmot Creek, Alberta, on the eastern flanks of the Canadian Rockies (Rothwell et al., 2016) and by the University of Calgary at Haig Glacier on the North American continental divide (Shea et al., 2005). An intensive field campaign will be conducted during May and June 2019 to obtain high-temporalresolution atmospheric conditions with an emphasis on precipitation on a longitudinal transect across the continental divide.

\section{Data availability}

Data described in this article may be downloaded from Zenodo (https://doi.org/10.5281/zenodo.1195043, Déry, 2017). CAMnet meteorological data are available as Excel spreadsheets in .xlsx format. The database comprises a specific directory for each station that includes (i) yearly .xlsx data files named according to the site location and year and (ii) a .docx file outlining metadata describing the location, quality control performed to evaluate the data, installed instruments and sampling parameters of each instrument per station. Data files are listed chronologically and follow the numerical order listed in Table 1. 


\section{Conclusions}

CAMnet was initiated from an interest and need to collect high-temporal-resolution data in elevated, complex terrain in a mountainous region where hydrometeorological data were previously quite sparse. Although challenges abound in obtaining high-quality data in a wilderness setting, our everexpanding hydrometeorological datasets provide insight to the weather and climate of the Cariboo Mountains and surrounding region. We have presented an overview of CAMnet station locations, the instruments used, parameters measured and the resulting datasets since 2006. The recent and planned addition of stations around Quesnel Lake and along the continental divide demonstrates the ongoing expansion of the network, while an extensive collection of metadata contributes to the understanding of data inconsistencies and possible errors. We encourage interested parties to contact the NHG for information on using CAMnet data or for further discussion on the establishment and maintenance of a mesoscale network of hydrometeorological stations.

Supplement. The supplement related to this article is available online at: https://doi.org/10.5194/essd-10-1655-2018-supplement.

Author contributions. SJD initiated the development of CAMnet and designed the present report. MAHH wrote the first draft of the manuscript with contributions from ARS, MT, HDT and SJD, and all contributed to the discussion of the database and manuscript refinement and revisions

Competing interests. The authors declare that they have no conflict of interest.

Special issue statement. This article is part of the special issue "Hydrometeorological data from mountain and alpine research catchments". It is not associated with a conference.

Acknowledgements. Thanks to UNBC, Future Forest Ecosystems Scientific Council, Environment and Climate Change Canada, Natural Sciences and Engineering Research Council of Canada through the Canadian Sea Ice and Snow Evolution network and the Discovery Grant and Research Tools and Instrumentation programs, Nechako Environmental Enhancement Fund, Canada Foundation for Innovation, Canadian Foundation for Climate and Atmospheric Sciences through the Western Canadian Cryospheric Network, BC Knowledge Development Fund, Global Water Futures and the Canada Research Chair program of the Government of Canada for funding. Thanks to Sam Albers, Michael Allchin, Darwyn Coxson, Art Fredeen, Scott Green, Rachel Hay, Rick Holmes, Peter Jackson, Brian Menounos, Jeremy Morris, Ken Otter, Phil Owens, Margot Parkes, Ellen Petticrew and Roger Wheate (all previously or currently affiliated with UNBC); Bernard Laval (UBC); Vanessa
Foord, Richard Kabzems and Pat Teti (FLNRORD); and many field assistants and volunteers for their contributions. Thank you to the staff at the QRRC (including past managers Rick Holmes and Sam Albers and the current manager Michael Allchin) and the people of Likely and the surrounding area for their continued support and interest in our research. Constructive and insightful comments from Phil Owens (UNBC), two anonymous referees and the Topical Editor (John Pomeroy, University of Saskatchewan) led to a much improved paper.

Edited by: John Pomeroy

Reviewed by: two anonymous referees

\section{References}

Beedle, M. J., Menounos, B., and Wheate, R.: Push moraines as climate proxy, Geophys. Res. Lett., 36, L20501, https://doi.org/10.1029/2009GL039533, 2009.

Beedle, M. J., Menounos, B., and Wheate, R.: Glacier change in the Cariboo Mountains, British Columbia, Canada (1952-2005), The Cryosphere, 9, 65-80, https://doi.org/10.5194/tc-9-65-2015, 2015.

Beniston, M.: Mountain weather and climate: A general overview and a focus on climatic change in the Alps, Hydrobiologia, 562, 3-16, https://doi.org/10.1007/s10750-005-1802-0, 2006.

Bradley, R. S., Keimig, F. T., and Diaz, H. F.: Projected temperature changes along the American cordillera and the planned GCOS network, Geophys. Res. Lett., 31, L16210, https://doi.org/10.1029/2004GL020229, 2004.

Burford, J. E., Déry, S. J., and Holmes, R. D.: Some aspects of the hydroclimatology of the Quesnel River Basin, British Columbia, Canada, Hydrol. Process., 23, 1529-1536, https://doi.org/10.1002/hyp.7253, 2009.

Campbell Scientific (Canada) Corp: Instruction Manual, RF401ASeries Spread Spectrum Radios, 51 pp., available at: https://s. campbellsci.com/documents/ca/manuals/rf401a-seriesman.pdf (last access: 25 March 2018), 2017.

Cherry, J. E., Tremblay, L. B., Déry, S. J., and Stieglitz, M.: Reconstructing solid precipitation from snow depth measurements and a land surface model, Water Resour. Res., 41, W09401, https://doi.org/10.1029/2005WR003965, 2005.

Déry, S.: Cariboo Alpine Mesonet (CAMnet) Database, Data set, Zenodo, https://doi.org/10.5281/zenodo.1195043, 2017.

Déry, S. J., Clifton, A., MacLeod, S., and Beedle, M. J.: Blowing snow fluxes in the Cariboo Mountains of British Columbia, Canada, Arct. Antarct. Alp. Res., 42, 188-197, https://doi.org/10.1657/1938-4246-42.2.188, 2010.

Déry, S. J., Hernández-Henríquez, M. A., Owens, P. N., Parkes, M. W., and Petticrew, E. L.: A century of hydrological variability and trends in the Fraser River Basin, Environ. Res. Lett., 7 , 024019, https://doi.org/10.1088/1748-9326/7/2/024019, 2012.

Déry, S. J., Knudsvig, H. K., Hernández-Henríquez, M. A., and Coxson, D. S.: Net snowpack accumulation and ablation characteristics in the Inland Temperate Rainforest of the Upper Fraser Basin, Canada, Hydrology, 1, 1-19, https://doi.org/10.3390/hydrology1010001, 2014.

Environment Climate Change Canada (ECCC): Manual of Surface Weather Observations, 7th Edn., 463 pp., 2015. 
Farley, A. L.: Atlas of British Columbia, University of British Columbia Press, Vancouver, BC, 136 pp., 1979.

Gubler, S., Hunziker, S., Begert, M., Croci-Maspoli, M., Konzelmann, T., Brönnimann, S., Schwierz, C., Oria, C., and Rosas, G.: The influence of station density on climate data homogenization, Int. J. Climatol., 37, 4670-4683, https://doi.org/10.1002/joc.5114, 2017.

Hasler, A., Geertsema, M., Foord, V., Gruber, S., and Noetzli, J.: The influence of surface characteristics, topography and continentality on mountain permafrost in British Columbia, The Cryosphere, 9, 1025-1038, https://doi.org/10.5194/tc-9-10252015, 2015.

Hay, R. W.: Sensitivity testing for the effects of sub-grid scale topography on snow evolution in the Canadian Land Surface Scheme, MSc Thesis, University of Northern British Columbia, Prince George, BC, 2018.

Kang, D. H., Gao, H., Shi, X., Islam, S. U., and Déry, S. J.: Impacts of a rapidly declining mountain snowpack on streamflow timing in Canada's Fraser River Basin, Sci. Rep.-UK, 6, 19299, https://doi.org/10.1038/srep19299, 2016.

Laval, B. E., Morrison, J., Potts, D. J., Carmack, E. C., Vagle, S., James, C., McLaughlin, F. A., and Foreman, M.: Winddriven summertime upwelling in a fjord-type lake and its impact on downstream river conditions: Quesnel Lake and River, British Columbia, Canada, J. Great Lakes Res., 34, 189-203, https://doi.org/10.3394/0380-1330(2008)34, 2008.

Leggat, M. S., Owens, P. N., Stott, T. A., Forrester, B. J., Déry, S. J., and Menounos, B.: Hydro-meteorological drivers and sources of suspended sediment flux in the proglacial zone of the retreating Castle Creek Glacier, Cariboo Mountains, British Columbia, Earth Surf. Proc. Land., 40, 1542-1559, https://doi.org/10.1002/esp.3755, 2015.

MacLeod, S. and Déry, S. J.: The Cariboo Alpine Mesonet, CMOS Bulletin SCMO, 35, 45-51, 2007.

McKenney, D. W., Hutchinson, M. F., Papadopol, P., Lawrence, K., Pedlar, J., Campbell, K., Milewska, E., Hopkinson, R. F., Price, D., and Owen, T.: Customized spatial climate models for North America, B. Am. Meteorol. Soc., 92, 1611-1622, https://doi.org/10.1175/2011BAMS3132.1, 2011.

Mekis, E., Donaldson, N., Reid, J., Zucconi, A., Hoover, J., Li, Q., Nitu, R., and Melo, S.: An overview of surface-based precipitation observations at Environment and Climate Change Canada, Atmos.-Ocean, 56, 71-95, 2018.

Miles, M. and Associates Ltd. for Ministry of Water Land and Air Protection: British Columbia's Climate-Related Observation Networks: An Adequacy Review, available at: http://www.for. gov.bc.ca/hfd/library/documents/bib94904a.pdf (5 June 2018), 2003.

Petticrew, E. L., Albers, S., Baldwin, S., Carmack, E. C., Déry, S. J., Gantner, N., Graves, K., Laval, B., Morrison, J., Owens, P. N., Selbie, D. T., and Vagle, S.: The impact of a catastrophic mine tailings impoundment spill into one of North America's largest fjord lake: Quesnel Lake, British Columbia, Canada, Geophys. Res. Lett., 42, 3347-3355, https://doi.org/10.1002/2015GL063345, 2015.

Radić, V., Menounos, B., Shea, J., Fitzpatrick, N., Tessema, M. A., and Déry, S. J.: Evaluation of different methods to model near-surface turbulent fluxes for a mountain glacier in the Cari- boo Mountains, BC, Canada, The Cryosphere, 11, 2897-2918, https://doi.org/10.5194/tc-11-2897-2017, 2017.

R Core Team: R: A language and environment for statistical computing, R Foundation for Statistical Computing, Vienna, Austria, R Foundation for Statistical Computing, available at: http: //www.r-project.org/, last access: 16 March 2014.

Rothwell, R., Hillman, G., and Pomeroy, J. W.: Marmot Creek experimental watershed study, Forestry Chron., 92, 32-36, 2016.

Schirmer, M. and Jamieson, B.: Verification of analysed and forecasted winter precipitation in complex terrain, The Cryosphere, 9, 587-601, https://doi.org/10.5194/tc-9-587-2015, 2015.

Sevruk, B.: Methods of correction for systematic error in point precipitation measurement for operational use, Oper. Hydrol. Rep. 21, 91 pp., World Meteorological Organization, Geneva, Switzerland, 1982.

Sharma, A. R.: Trends and elevational dependence of the hydroclimatology of the Cariboo Mountains, British Columbia, MSc Thesis, University of Northern British Columbia, Prince George, BC, https://doi.org/10.13140/RG.2.1.2121.9444, 2014.

Sharma, A. R. and Déry, S. J.: Elevational dependence of air temperature variability and trends in British Columbia's Cariboo Mountains, 1950-2010, Atmos.-Ocean, 54, 153-170, https://doi.org/10.1080/07055900.2016.1146571, 2016.

Shea, J. M., Anslow, F. S., and Marshall, S. J.: Hydrometeorological relationships on Haig Glacier, Alberta, Canada, Ann. Glaciol., 40, 52-60, https://doi.org/10.3189/172756405781813465, 2005.

Stevenson, S. K., Armleder, H. M., Arsenault, A., Coxson, D., Delong, S. C., and Jull, M.: British Columbia's Inland Rainforest, UBC Press, Vancouver, BC, Canada, 432 pp., 2011.

Stott, T. A., Leggat, M. S., Owens, P. N., Forrester, B. J., Déry, S. J., and Menounos, B.: Suspended sediment dynamics in the proglacial zone of the rapidly retreating Castle Creek Glacier, British Columbia, Canada, in: Sources-to-Sink Fluxes in Undisturbed Cold Environments, edited by: Beylich, A. A., Dixon, J. C., and Zwolinski, Z., Cambridge University Press, 313-325, 2016.

Tong, J., Déry, S. J., and Jackson, P. L.: Topographic control of snow distribution in an alpine watershed of western Canada inferred from spatially-filtered MODIS snow products, Hydrol. Earth Syst. Sci., 13, 319-326, https://doi.org/10.5194/hess-13319-2009, 2009a.

Tong, J., Déry, S. J., and Jackson, P. L.: Interrelationships between MODIS/Terra remotely sensed snow cover and the hydrometeorology of the Quesnel River Basin, British Columbia, Canada, Hydrol. Earth Syst. Sci., 13, 1439-1452, https://doi.org/10.5194/hess-13-1439-2009, 2009b.

Tong, J., Déry, S. J., Jackson, P. L., and Derksen, C.: Testing snow water equivalent retrieval algorithms for passive microwave remote sensing in an alpine watershed of western Canada, Can. J. Remote Sens., 36, S74-S86, https://doi.org/10.5589/m10-009, 2010.

Wang, T., Hamann, A., Spittlehouse, D. L., and Murdock, T. Q.: ClimateWNA - High resolution spatial climate data for western North America, J. Appl. Meteorol. Clim., 51, 16-29, 2012.

Younas, W., Hay, R. W., MacDonald, M. K., Islam, S. U., and Déry, S. J.: A strategy to represent impacts of subgrid-scale topography on snow evolution in the Canadian Land Surface Scheme, Ann. Glaciol., 58, 1-10, 2017. 